


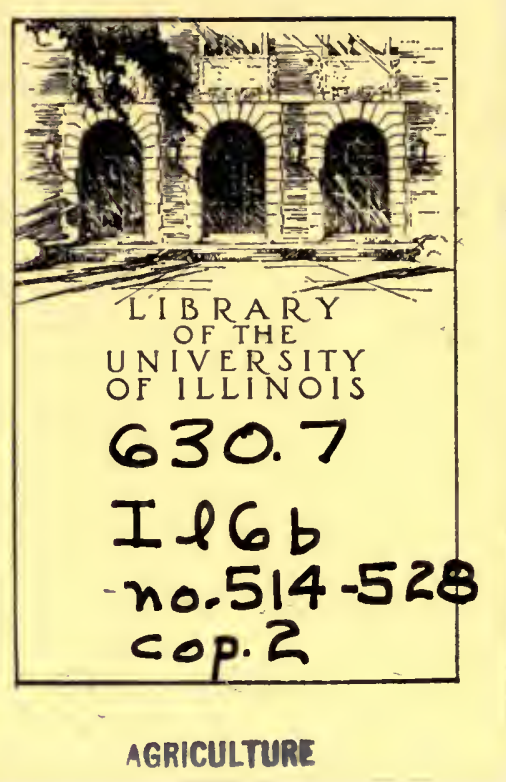


NOTICE: Return or renew all Library Materials! The Minimum Fee for each Lost Book is $\mathbf{\$ 5 0 . 0 0}$.

The person charging this material is responsible for its return to the library from which it was withdrawn on or before the Latest Date stamped below.

Theft, mutilation, end underlining of books are reasons for disclpllnary action and may result in dismissal from the University.

To renew call Telephone Center, 333-8400

UNIVERSITY OF ILLINOIS LIBRARY AT URBANA-CHAMPAIGN

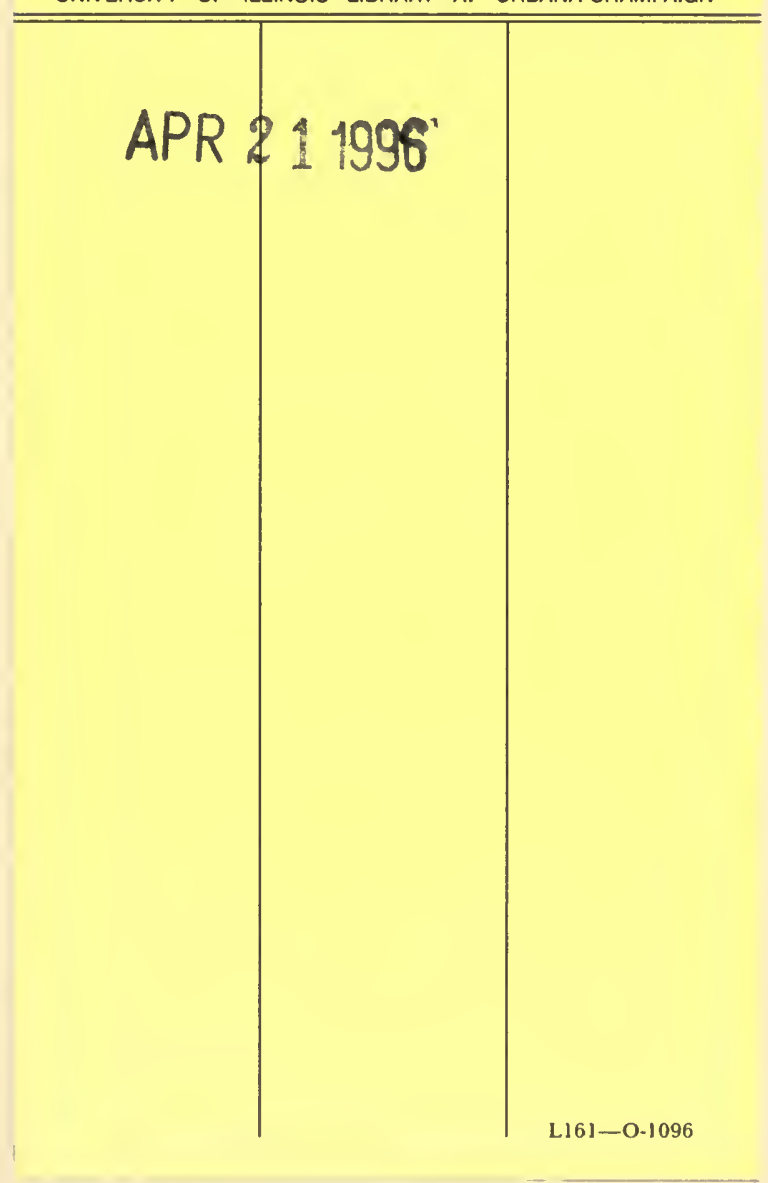






\title{
Chemical Composition
}

\section{of HAY AND \\ FORAGE CROPS}

\author{
As Affected \\ by Various Soil \\ Treatments ...
}

By H. J. Snider

Bulletin 518 - UNIVERSITY OF ILLINOIS AGRICULTURAL EXPERIMENT STATION 
tein content (protein is nitrogen $\times 6.25$ ). Of the elements determined in legumes in this study, nitrogen exceeded all others in amount. In nonlegumes potassium greatly exceeded nitrogen. Legumes contained a larger total amount of minerals - phosphorus, potassium, calcium, magnesium, iron, and manganese. Seven legumes averaged 46.3 pounds of nitrogen per ton of dry hay and 63.9 pounds of minerals, whereas the six principal nonlegumes averaged 22.2 pounds of nitrogen per ton of dry hay and 48.7 pounds of minerals (see Table 1 ).

\section{Table 1. - HAY AND FORAGE CROPS: Chemical Composition Over a Period of Years}

\begin{tabular}{|c|c|c|c|c|c|c|c|c|c|}
\hline \multirow{2}{*}{ Crop } & \multirow{2}{*}{$\begin{array}{l}\text { Number } \\
\text { of } \\
\text { samples" }\end{array}$} & $\mathbf{N}$ & Protein & $\mathbf{P}$ & $\mathbf{K}$ & $\mathrm{Ca}$ & $\mathrm{Mg}$ & $\mathrm{Fe}$ & $\mathrm{Mn}$ \\
\hline & & \multicolumn{8}{|c|}{ Average pounds per ton of crop } \\
\hline 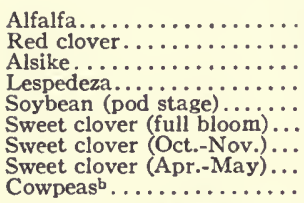 & $\begin{array}{rr}\because \quad 50 \\
\because \quad 50 \\
\because \quad 20 \\
\because \quad 50 \\
\because \quad 50 \\
\because \quad 7 \\
\because \quad 17 \\
\because \quad 30 \\
\therefore \quad 3\end{array}$ & $\begin{array}{l}55.0 \\
47.4 \\
47.0 \\
40.4 \\
43.6 \\
34.4 \\
41.4 \\
69.0 \\
49.6\end{array}$ & $\begin{array}{l}344 \\
296 \\
294 \\
252 \\
272 \\
215 \\
259 \\
431 \\
310\end{array}$ & $\begin{array}{l}3.6 \\
3.2 \\
4.2 \\
2.9 \\
3.4 \\
3.0 \\
2.2 \\
6.0 \\
3.5\end{array}$ & $\begin{array}{l}25.0 \\
26.0 \\
22.4 \\
18.9 \\
17.8 \\
19.4 \\
16.0 \\
32.0 \\
25.2\end{array}$ & $\begin{array}{l}35.0 \\
29.4 \\
26.2 \\
17.0 \\
25.0 \\
42.0 \\
27.0 \\
32.8 \\
30.2\end{array}$ & $\begin{array}{r}9.8 \\
9.2 \\
10.6 \\
5.7 \\
17.4 \\
13.4 \\
12.4 \\
11.4 \\
14.2\end{array}$ & $\begin{array}{l}.16 \\
.28 \\
.30 \\
.20 \\
.46 \\
.30 \\
.38\end{array}$ & $\begin{array}{l}.02 \\
.10 \\
.09 \\
.14 \\
.17 \\
.20 \\
.97\end{array}$ \\
\hline 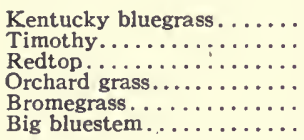 & $\begin{array}{ll}\because & 50 \\
\therefore \quad 50 \\
\therefore \quad 50 \\
\therefore \quad 30 \\
\therefore \quad & 50 \\
\cdots & 10\end{array}$ & $\begin{array}{l}29.4 \\
19.6 \\
21.2 \\
19.4 \\
29.8 \\
21.4\end{array}$ & $\begin{array}{l}184 \\
122 \\
132 \\
121 \\
186 \\
134\end{array}$ & $\begin{array}{l}3.8 \\
3.0 \\
3.4 \\
3.6 \\
3.4 \\
3.0\end{array}$ & $\begin{array}{l}32.8 \\
31.4 \\
31.8 \\
38.0 \\
44.3 \\
29.6\end{array}$ & $\begin{array}{l}6.2 \\
5.6 \\
8.4 \\
5.4 \\
8.0 \\
7.6\end{array}$ & $\begin{array}{l}4.0 \\
3.6 \\
4.4 \\
4.2 \\
3.0 \\
4.1\end{array}$ & $\begin{array}{l}.26 \\
.16 \\
.18 \\
.16 \\
.12 \\
.29\end{array}$ & $\begin{array}{l}.19 \\
.14 \\
.43 \\
.56 \\
.24 \\
.12\end{array}$ \\
\hline $\begin{array}{l}\text { Cornstalks }{ }^{\circ} \ldots \ldots \ldots \ldots \ldots \ldots \\
\text { Wheat straw. } \ldots \ldots \ldots \ldots \ldots \\
\text { Oat straw...... }\end{array}$ & $\begin{array}{l}\quad 50 \\
\because \quad 20 \\
\therefore \quad 10\end{array}$ & $\begin{array}{r}14.8 \\
8.0 \\
13.8\end{array}$ & $\begin{array}{l}92 \\
50 \\
83\end{array}$ & $\begin{array}{l}1.8 \\
1.8\end{array}$ & $\begin{array}{l}23.0 \\
14.6 \\
31.0\end{array}$ & $\begin{array}{l}9.8 \\
3.2 \\
5.0\end{array}$ & $\begin{array}{l}8.4 \\
2.2 \\
3.4\end{array}$ & $\begin{array}{l}.36 \\
\cdots \\
\cdots\end{array}$ & $\begin{array}{l}.28 \\
\cdots \\
\cdots\end{array}$ \\
\hline
\end{tabular}

Samples were taken from experiment fields and farms in various parts of Illinois.

b Cowpeas from Sparta field only.

- Cornstalks include blades, sheath, and husk as well as stalk.

Symbols used in tables. $\mathrm{DM}=$ dry matter (1b./A = pounds an acre); $\mathrm{N}=$ total nitrogen; $\mathbf{P}=$ phosphorus (when referring to soil composition it refers to phosphorus soluble in weak acid $\left(.002 \mathrm{~N} \mathrm{H}_{2} \mathrm{SO}_{4}\right) ; \mathrm{K}=$ potassium (when referring to soil treatment, it means muriate of potash); $\mathbf{C a}=$ calcium; $\mathbf{M g}=$ magnesium; (when referring to soil composition, $\mathrm{K}, \mathrm{Ca}, \mathrm{Mg}$ are replaceable); $\mathbf{F e}=$ iron; $\mathbf{M n}=$ manganese.

$\mathbf{M}=$ manure; $\mathbf{L}=$ limestone; $\mathbf{r P}=$ rock phosphate; $\mathbf{s} \mathbf{P}=$ superphosphate; $\mathrm{bP}=$ bone meal; $\mathbf{R}=$ crop residues.

$\left(\mathrm{NH}_{4}\right)_{2} \mathrm{SO}_{4}=$ ammonium sulfate, Uramon = trade name for urea; $\mathrm{CaCN}_{2}$ $=$ calcium cyanamide; $\mathrm{NaNO}_{3}=$ sodium nitrate; $\mathbf{M n S O}_{4}=$ manganese sulfate; $2-12-6=$ mixed fertilizer containing N-P-K.

$\mathrm{pH}=$ degree of acidity. ( $\mathrm{pH} 7$ means a neutral soil; values above $\mathrm{pH} 7$ indicate alkalinity and the higher the values the more alkaline the soil; values below 7 indicate acidity, and the lower the value the greater the acidity.) 
Low phosphorus content may injure livestock. Since phosphorus is taken up by most crops in proportion to its availability in soils, the amount of it in the soil will affect the feeding value of hay and forage. In many sections of the country phosphorus deficiencies in hay and forage crops are handicaps to the raising of livestock. In fact such shortages may cause a serious animal disease, known as aphosphorosis.

Because the areas reported as deficient in phosphorus have usually been remote from Illinois, many people have assumed that Illinois farms have ample supplies of this mineral. A large proportion of soils in various sections of the state are, however, now known to be deficient in available phosphorus.

The danger point in the phosphorus content of hay and forage has been rather definitely stated by a number of investigators. Hamilton ${ }^{3 *}$ of the Illinois Station summarized his views as follows:

"Aphosphorosis ... is primarily a disease associated with phosphorusdeficient soils and consequently phosphorus-deficient forages. When animals subsist for long periods of time on forages which contain less than about .15 percent phosphorus [ 3 pounds a ton] on the dry basis, aphosphorosis is a possibility, altho there is usually no consistent and serious damage until the phosphorus content drops below .12 or .13 percent [ 2.4 or 2.6 pounds per ton]."

Hamilton's statement is supported by evidence from various regions. Fraps and Fudge ${ }^{2 *}$ of the Texas Station state that when the phosphorus content of forage falls below 2.6 pounds a ton, the forage is definitely deficient in phosphorus. Archibald and Bennett ${ }^{1 *}$ of the Massachusetts Station report that the danger line is 3 pounds of phosphorus per ton of forage and that disease becomes prevalent among animals that are fed forage containing as little as 2 pounds of phosphorus a ton. Nygard ${ }^{5 *}$ of the Montana Station reported bonechewing by cows when the phosphorus content of their forage was no lower than 2.9 pounds a ton. In a progress report from the Tennessee Station (1939-1942), Jacob et al. 4* $^{*}$ stated that calves after feeding for 56 days on low-phosphorus red-clover hay ( 2 pounds of phosphorus per ton) refused considerable of their feed. These investigators also recommend red-clover hay as safe for feeding when it contains from 3.2 pounds to 4 pounds of phosphorus per ton.

These reports indicate that the feeding of hay and forage that contain less than 3 pounds of phosphorus per ton may cause injury to livestock.

* All superior figures with asterisks refer to literature citations on page 292. 


\section{PLAN OF THE EXPERIMENT \\ Methods of Sampling Plant Materials ${ }^{1}$}

Samples of legumes and nonlegumes were collected from established experiment fields and from cooperative fertilizer experiments on farms in various sections of the state (see map, page 258). Samples of bluestem were collected from fencerows, roadways, and other uncultivated places. The legume samples were collected when the crop was harvested for hay. Sweet clover was sampled at different stages of growth as is noted in various tables. The nonlegumes - bluegrass, timothy, redtop, orchard grass, and bromegrass - were sampled when the crop was fully headed and, unless otherwise stated, mature enough for hay. Cornstalks were sampled when the husks were dry and the grain fully dented. Wheat and oat straw were taken at the time of threshing.

\section{Crop Rotation and Soil Treatment}

On the permanent experiment fields a four-year rotation of crops was generally used. This rotation consisted mostly of corn, oats, a legume, and wheat. The legume was red clover, alfalfa, lespedeza, or a mixture of some of these legumes with some grass, the crop grown depending on the location. The wheat crop usually contained a seeding of sweet clover for green manure.

Manure (M) was returned to the soil in amounts equal to the dry weight of the crops removed from the land.

Residues (R) usually consisted of a green-manure crop of sweet clover or lespedeza. Also the last cutting of legume hay was plowed under. Cornstalks, and on some fields wheat and oat straw, were added to the residues treatment.

Limestone (L) was added in amounts large enough to grow the desired legumes, that is - to maintain a reaction of approximately $\mathrm{pH}$ 6.0.

Rock phosphate (rP) was added to the permanent experiment fields over a period of years until a total of 4 tons an acre had been applied.

${ }^{1}$ All samples collected were kept relatively free of soil and other sources of contamination. Samples of roots were carefully washed to remove soil particles. All samples were oven-dried and then ground in a Wiley mill. They were oxidized by the nitricperchloric acid wet-ashing method. Amounts of nitrogen, phosphorus, potassium, calcium, and magnesium were determined by currently standard methods. Amounts of iron were determined colorimetrically with potassium thiocyanate. Manganese was determined colorimetrically with potassium periodate. 
Superphosphate (sP) (20 percent sP unless otherwise stated) was applied in rather small amounts -200 to 300 pounds and on some fields 500 pounds an acre each year in the rotation.

Muriate of potash (K) was applied at the rate of 100 pounds an acre for corn, 200 pounds for wheat, and 100 pounds for the legume crop.

\section{COMPOSITION OF THE LEGUMES}

\section{Alfalfa}

As a hay crop, alfalfa is of first importance on Illinois corn-belt farms and in other sections of the state where soil conditions are favorable to its growth. Often referred to as the best of all degumes, it is given this rating mainly because of its relatively high content of protein and minerals. Alfalfa may be used with success in various crop rotations and may be seeded in mixtures of other legumes and with grasses. It long ago proved its excellence in systems of soil improvement and conservation.

The nitrogen and protein content of alfalfa is apparently not dependent upon the total nitrogen in the soils where the alfalfa is grown. Alfalfa hay from the Oquawka field, where the total nitrogen in the soil was only 900 pounds an acre, was equal in nitrogen to the hay from the Easton and Minonk fields, where the soils contained seven to ten times as much nitrogen as the Oquawka field and were relatively much more productive (Tables 2 and 3 ).

Chemical analyses (Tables 2 to 5 ) show that on some Illinois soils the amounts of phosphorus in the alfalfa hay were as low as 2.2 to 2.8 pounds per ton of hay. On soils which were treated with phosphate fertilizers, the phosphorus in the hay ranged from 3 pounds per ton to 5.6 pounds per ton.

The phosphorus content of the hay varied in the different cuttings, probably because of periods of rainfall or drouth during the various growth stages. Liming the soil tended to reduce the amount of phosphorus in the hay. This was noticeable on the Hartsburg and Joliet fields, where alfalfa grew even on the unlimed plots. The amount of this reduction varied from .2 pound per ton to 1.2 pounds per ton (Table 2). Additions of rock phosphate and superphosphate substantially increased the phosphorus content of the alfalfa on the Hartsburg field; rock phosphate increased the phosphorus content on the Joliet field (superphosphate was not used on this field). 
Table 2. - ALFALFA HAY: Yield and Chemical Composition When Grown on Soils of Different Levels of Productivity Under Different Soil Treatments

\begin{tabular}{|c|c|c|c|c|c|c|c|}
\hline \multirow{2}{*}{ Soil treatment } & \multirow{2}{*}{$\begin{array}{l}\text { Hay } \\
\text { yield } \\
\text { lb./A }\end{array}$} & $\mathrm{N}$ & Protein & $\mathbf{P}$ & $\mathrm{K}$ & $\mathrm{Ca}$ & $\mathrm{Mg}$ \\
\hline & & \multicolumn{6}{|c|}{ Pounds per ton of hay } \\
\hline \multicolumn{8}{|c|}{ Carlinville, 1936} \\
\hline & \multicolumn{2}{|c|}{ June 2} & & & & \\
\hline 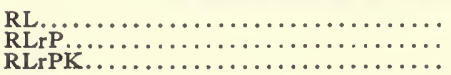 & $\begin{array}{l}3350 \\
4810 \\
4190\end{array}$ & $\begin{array}{l}56.8 \\
57.6 \\
57.2\end{array}$ & $\begin{array}{l}355 \\
360 \\
358\end{array}$ & $\begin{array}{l}3.0 \\
3.2 \\
3.8\end{array}$ & $\begin{array}{l}23.4 \\
18.2 \\
23.4\end{array}$ & $\begin{array}{l}40.4 \\
42.8 \\
42.4\end{array}$ & $\begin{array}{l}9.4 \\
9.4 \\
9.4\end{array}$ \\
\hline \multicolumn{8}{|c|}{ July 14} \\
\hline $\begin{array}{l}\operatorname{RL} \ldots \ldots \ldots \ldots \\
\operatorname{RLrPK} \\
\operatorname{RL} \ldots \ldots \ldots\end{array}$ & $\begin{array}{l}11 \\
1850 \\
1850 \\
1850\end{array}$ & $\begin{array}{l}56.8 \\
56.8 \\
59.2\end{array}$ & $\begin{array}{l}355 \\
355 \\
370\end{array}$ & $\begin{array}{l}2.6 \\
3.2 \\
3.6\end{array}$ & $\begin{array}{l}22.0 \\
22.0 \\
24.0\end{array}$ & $\begin{array}{l}40.8 \\
40.4 \\
34.4\end{array}$ & $\begin{array}{l}9.4 \\
9.4 \\
9.1\end{array}$ \\
\hline \multicolumn{8}{|c|}{ Seplember 4} \\
\hline 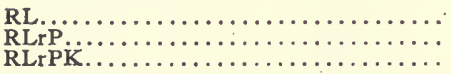 & $\begin{array}{ll}2 & 000 \\
2 & 510 \\
2 & 100\end{array}$ & $\begin{array}{l}48.8 \\
47.2 \\
46.4\end{array}$ & $\begin{array}{l}305 \\
295 \\
290\end{array}$ & $\begin{array}{l}2.8 \\
3.0 \\
3.0\end{array}$ & $\begin{array}{l}23.4 \\
22.4 \\
23.4\end{array}$ & $\begin{array}{l}52.4 \\
46.8 \\
53.6\end{array}$ & $\begin{array}{r}13.4 \\
11.5 \\
9.6\end{array}$ \\
\hline
\end{tabular}

Easton, June 1, 1940

\begin{tabular}{|c|c|c|c|c|c|c|c|}
\hline 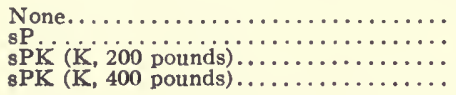 & $\begin{array}{ll}2 & 400 \\
2 & 400 \\
3 & 040 \\
2 & 980\end{array}$ & $\begin{array}{l}60.8 \\
60.8 \\
63.8 \\
56.4\end{array}$ & $\begin{array}{l}380 \\
380 \\
398 \\
352\end{array}$ & $\begin{array}{l}3.8 \\
4.0 \\
4.4 \\
4.0\end{array}$ & $\begin{array}{l}24.8 \\
15.6 \\
32.6 \\
45.6\end{array}$ & $\begin{array}{l}49.2 \\
48.4 \\
36.8 \\
29.6\end{array}$ & $\begin{array}{l}8.6 \\
9.2 \\
6.8 \\
4.4\end{array}$ \\
\hline
\end{tabular}

Elizabethtown, May 29, 1936

\begin{tabular}{|c|c|c|c|c|c|c|c|}
\hline 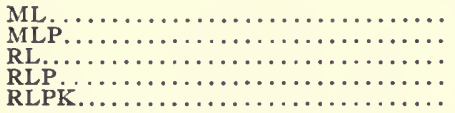 & $\begin{array}{ll}2 & 530 \\
4 & 290 \\
& 400 \\
3 & 200 \\
3 & 460\end{array}$ & $\begin{array}{l}61.6 \\
61.2 \\
54.4 \\
62.8 \\
54.8\end{array}$ & $\begin{array}{l}385 \\
382 \\
340 \\
392 \\
342\end{array}$ & $\begin{array}{l}2.8 \\
3.4 \\
2.8 \\
3.6 \\
3.2\end{array}$ & $\begin{array}{l}42.4 \\
40.0 \\
32.6 \\
20.8 \\
36.4\end{array}$ & $\begin{array}{l}25.2 \\
28.0 \\
30.4 \\
40.4 \\
27.2\end{array}$ & $\begin{array}{r}6.4 \\
8.4 \\
10.2 \\
11.2 \\
9.4\end{array}$ \\
\hline
\end{tabular}

Ewing, June 4, 1936

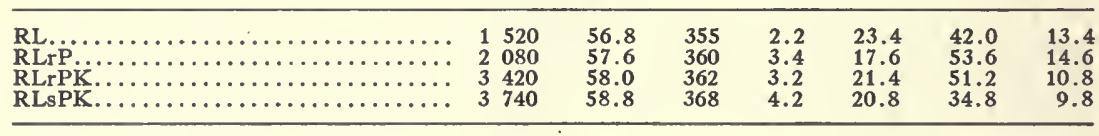

Hartsburg, 1937

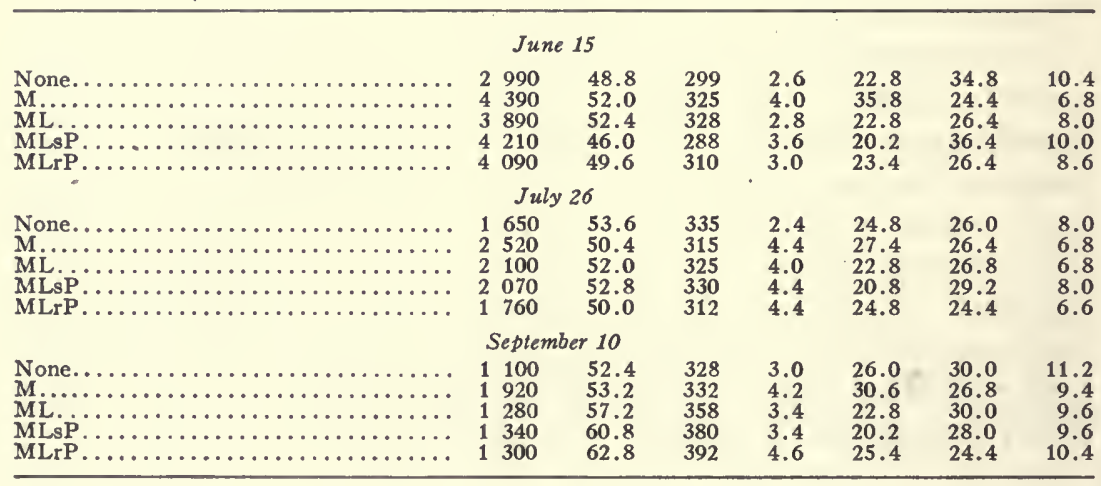


The potassium content of the alfalfa hay was for the most part proportional to the amounts available in the soils (Tables 2 and 3 ). This may be illustrated by experiments on two fields. The Minonk

\section{Table 3. - COMPOSITION OF SOIL:" Ten Experiment Fields Treated With Residues-Limestone and One Untreated Field}

\begin{tabular}{|c|c|c|c|c|c|c|}
\hline \multirow{2}{*}{ Field } & $\mathrm{pH}$ & $\mathbf{N}$ & $\mathbf{P}$ & $\mathbf{K}$ & $\mathrm{Ca}$ & $\mathbf{M g}$ \\
\hline & \multicolumn{6}{|c|}{ Pounds per acre } \\
\hline \multicolumn{7}{|c|}{ Southern Illinois } \\
\hline 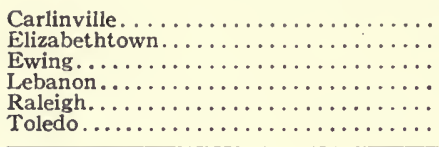 & $\begin{array}{l}6.8 \\
6.2 \\
6.6 \\
6.5 \\
6.5 \\
6.2\end{array}$ & $\begin{array}{ll}3 & 160 \\
1 & 680 \\
1 & 900 \\
2 & 860 \\
2 & 920 \\
2 & 440\end{array}$ & $\begin{array}{r}50 \\
14 \\
26 \\
100 \\
20 \\
32\end{array}$ & $\begin{array}{r}200 \\
180 \\
70 \\
140 \\
100 \\
70\end{array}$ & $\begin{array}{ll}7 & 760 \\
3 & 280 \\
2 & 760 \\
5 & 040 \\
4 & 040 \\
3 & 000\end{array}$ & $\begin{array}{r}1000 \\
400 \\
170 \\
480 \\
140 \\
290\end{array}$ \\
\hline \multicolumn{7}{|c|}{ Central Illinois } \\
\hline 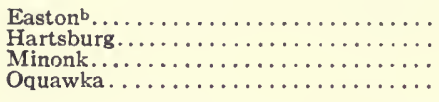 & $\begin{array}{l}8.1 \\
6.6 \\
7.2 \\
6.4\end{array}$ & $\begin{array}{ll}7 & 240 \\
5 & 280 \\
9 & 280 \\
900\end{array}$ & $\begin{array}{r}60 \\
220 \\
140 \\
60\end{array}$ & $\begin{array}{r}90 \\
320 \\
360 \\
60\end{array}$ & $\begin{array}{rr}44 & 840 \\
11 & 440 \\
15 & 760 \\
1 & 400\end{array}$ & $\begin{array}{ll}1 & 250 \\
3 & 870 \\
3 & 320 \\
& 140\end{array}$ \\
\hline & \multicolumn{2}{|c|}{ Northern Illinois } & $\cdot$ & & & \\
\hline Joliet $\ldots \ldots \ldots \ldots \ldots \ldots \ldots \ldots \ldots$ & 6.5 & 4960 & 20 & 210 & 7720 & 1550 \\
\hline
\end{tabular}

Topsoil, about 7 inches.
b Untreated soil on the Easton field is included in the table to show variation of soils on which alfalfa grew.

field soil had a potassium content of 360 pounds an acre, and the alfalfa grown on the soil contained 30 pounds of potassium a ton. On the Toledo field the potassium content of the soil was 70 pounds per acre and that of the alfalfa was 9 pounds per ton (Table 2).

Seasonal conditions also caused a variation in the percentage of potassium in the hay. It has been noted that in seasons of abundant rainfall relatively more potassium may be taken up by hay crops than is taken up during a dry season.

The calcium content of alfalfa hay was relatively high (Table 1 ); thus alfalfa is a good source of calcium for animals. Altho the magnesium content was much lower than the calcium content, a more-orless definite relation exists between these two elements in plants. On the basis of chemical equivalents there is a constant relation between potassium on the one hand and calcium and magnesium on the other. In plants this relation may be disturbed by deficiencies of potassium in the soil. Under normal soil conditions, however, it is quite constant and potassium is the dominating element in the relationship. 
Effect of date of cutting. There was no indication that the first, second, or third cutting of alfalfa was greatly superior in feeding quality as judged by total protein content. Neither was there any outstanding difference in mineral content of the three cuttings (Table 2).

Seasonal variation on one field. During three successive years on the Smith farm there was considerable difference in the amounts of protein in the second cuttings of alfalfa hay (Table 4). Because of seasonal differences the 1941 hay crop averaged 100 pounds more protein per ton than the 1939 crop. Phosphate applied to this field maintained a relatively high level of phosphorus in the hay and also substantially increased the yields of hay.

Amounts and composition of roots and tops. Alfalfa root growth was relatively small at the time of the first cutting, June 2, but had increased considerably in bulk and declined slightly in composition at the time of the third cutting September 4 (Table 5). Altho increase in

Table 4. - ALFALFA HAY: Yield and Chemical Composition in Successive Years Under Different Soil Treatments, and Phosphorus

Recovered per Acre in the Hay

(Smith farm, Shelby county, central Illinois)

\begin{tabular}{|c|c|c|c|c|c|c|c|c|c|}
\hline \multicolumn{10}{|c|}{ Yield and chemical composition in successive years } \\
\hline \multirow{2}{*}{ Soil treatment } & \multirow{2}{*}{$\begin{array}{l}\text { Hay } \\
\text { lb./A }\end{array}$} & $\mathbf{N}$ & Protein & $\mathbf{P}$ & $\mathbf{K}$ & $\mathrm{Ca}$ & $\mathrm{Mg}$ & $\mathrm{Fe}$ & $\mathrm{Mn}$ \\
\hline & & \multicolumn{8}{|c|}{ Pounds per ton of hay } \\
\hline \multicolumn{10}{|c|}{ July 7,1939} \\
\hline $\begin{array}{l}\mathrm{L}+\ldots \mathrm{P} \\
\mathrm{L}+\mathrm{rP} \\
225000 \text { pounds } \\
22 . . .\end{array}$ & $\begin{array}{ll}1 & 780 \\
2 & 590 \\
3 & 350\end{array}$ & $\begin{array}{l}60.4 \\
65.2 \\
60.0\end{array}$ & $\begin{array}{l}378 \\
408 \\
375\end{array}$ & $\begin{array}{l}2.8 \\
3.8 \\
4.2\end{array}$ & $\begin{array}{l}48.8 \\
40.0 \\
41.8\end{array}$ & $\begin{array}{l}21.6 \\
24.8 \\
21.6\end{array}$ & $\begin{array}{l}6.4 \\
8.6 \\
6.4\end{array}$ & $\begin{array}{l}.02 \\
.13 \\
.01\end{array}$ & $\begin{array}{l}.07 \\
.07 \\
.04\end{array}$ \\
\hline \multicolumn{10}{|c|}{ July 5, 1940} \\
\hline 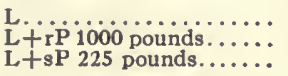 & $\begin{array}{ll}1 & 530 \\
2 & 380 \\
2 & 550\end{array}$ & $\begin{array}{l}60.0 \\
67.2 \\
64.4\end{array}$ & $\begin{array}{l}375 \\
420 \\
402\end{array}$ & $\begin{array}{l}2.6 \\
4.0 \\
4.0\end{array}$ & $\begin{array}{l}37.8 \\
32.6 \\
32.6\end{array}$ & $\begin{array}{l}32.4 \\
32.8 \\
34.8\end{array}$ & $\begin{array}{l}7.8 \\
9.0 \\
8.2\end{array}$ & $\begin{array}{l}.30 \\
.20 \\
.22\end{array}$ & $\begin{array}{l}.02 \\
.02 \\
.02\end{array}$ \\
\hline \multicolumn{10}{|c|}{ July 1,1941} \\
\hline 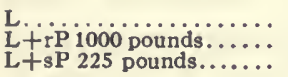 & $\begin{array}{ll}1 & 570 \\
2 & 160 \\
2 & 220\end{array}$ & $\begin{array}{l}78.8 \\
78.4 \\
76.4\end{array}$ & $\begin{array}{l}492 \\
490 \\
478\end{array}$ & $\begin{array}{l}4.0 \\
4.0 \\
4.2\end{array}$ & $\begin{array}{l}48.8 \\
41.8 \\
49.6\end{array}$ & $\begin{array}{l}31.2 \\
29.6 \\
30.4\end{array}$ & $\begin{array}{l}9.2 \\
9.2 \\
9.0\end{array}$ & $\begin{array}{l}.06 \\
.04 \\
.04\end{array}$ & $\begin{array}{l}.05 \\
.05 \\
.04\end{array}$ \\
\hline
\end{tabular}

Phosphorus in phosphate applications and recovered in hay

\begin{tabular}{|c|c|c|c|c|}
\hline & \multirow{2}{*}{$\begin{array}{l}\text { Phosphorus in } \\
\text { applications }\end{array}$} & \multirow{2}{*}{ Date sampled } & \multicolumn{2}{|c|}{ Phosphorus recovered in hay } \\
\hline & & & $\begin{array}{l}\text { Pounds per } \\
\text { acre }\end{array}$ & Percent \\
\hline $\mathbf{L}+\mathrm{rP}$. & 140 pounds. & $\begin{array}{l}\text { July } 7,1939 . \\
\text { July } 5,1940 . \\
\text { July } 1,1941 .\end{array}$ & $\begin{array}{ll}\ldots \ldots & 4.8 \\
\ldots \ldots & 5.5 \\
\ldots \ldots & 2.3\end{array}$ & $\begin{array}{l}3.4 \\
3.2 \\
1.6\end{array}$ \\
\hline $\mathrm{L}+\mathbf{s P a}$. & 44 pounds... & $\begin{array}{l}\text { July } 7,1939 . \\
\text { July } 5,1940 \text {. } \\
\text { July } 1,1941 .\end{array}$ & $\begin{array}{ll}\ldots \ldots & 9.1 \\
\cdots \cdots & 6.2 \\
\cdots \cdots & 3.0\end{array}$ & $\begin{array}{r}20.2 \\
13.8 \\
5.8\end{array}$ \\
\hline
\end{tabular}

- Superphosphate (0-45-0). 
Table 5. - PARTS OF ALFALFA PLANT: Yield and Chemical Composition at Different Harvest Dates Under Different Soil Treatments

\begin{tabular}{|c|c|c|c|c|c|c|c|c|}
\hline \multirow{2}{*}{ Soil treatment } & \multirow{2}{*}{ Part of plant } & \multirow{2}{*}{$\begin{array}{l}\text { Dry } \\
\text { matter } \\
\text { lb./A }\end{array}$} & $\mathrm{N}$ & Protein & $\mathbf{P}$ & K & $\mathrm{Ca}$ & $\mathrm{Mg}$ \\
\hline & & & \multicolumn{6}{|c|}{ Pounds per ton of crop } \\
\hline \multicolumn{9}{|c|}{ Carlinville, 1937} \\
\hline \multicolumn{9}{|c|}{ June 2} \\
\hline RL........... & $\begin{array}{l}\text { Tops................ } \\
\text { Roots......... }\end{array}$ & $\begin{array}{ll}3 & 350 \\
1 & 690\end{array}$ & $\begin{array}{l}56.8 \\
53.6\end{array}$ & $\begin{array}{l}355 \\
335\end{array}$ & $\begin{array}{l}3.0 \\
2.8\end{array}$ & $\begin{array}{l}23.4 \\
15.6\end{array}$ & $\begin{array}{r}40.4 \\
8.0\end{array}$ & $\begin{array}{l}9.4 \\
6.6\end{array}$ \\
\hline RLrP.......... & $\begin{array}{l}\text { Tops............... } \\
\text { Roots.......... }\end{array}$ & $\begin{array}{l}4810 \\
1470\end{array}$ & $\begin{array}{l}57.6 \\
55.2\end{array}$ & $\begin{array}{l}360 \\
345\end{array}$ & $\begin{array}{l}3.2 \\
4.8\end{array}$ & $\begin{array}{l}18.2 \\
11.8\end{array}$ & $\begin{array}{r}42.8 \\
9.2\end{array}$ & $\begin{array}{l}9.4 \\
6.8\end{array}$ \\
\hline RLrPK. . & $\begin{array}{l}\text { Tops............... } \\
\text { Roots.......... }\end{array}$ & $\begin{array}{ll}4 & 190 \\
1 & 420\end{array}$ & $\begin{array}{l}57.2 \\
59.6\end{array}$ & $\begin{array}{l}358 \\
372\end{array}$ & $\begin{array}{l}3.8 \\
5.2\end{array}$ & $\begin{array}{l}23.4 \\
13.6\end{array}$ & $\begin{array}{r}42.4 \\
8.0\end{array}$ & $\begin{array}{l}9.4 \\
5.8\end{array}$ \\
\hline \multicolumn{9}{|c|}{ September 4} \\
\hline RL........... & $\begin{array}{l}\text { Tops............... } \\
\text { Roots........... }\end{array}$ & $\begin{array}{ll}2 & 000 \\
2 & 120\end{array}$ & $\begin{array}{l}48.8 \\
51.2\end{array}$ & $\begin{array}{l}305 \\
320\end{array}$ & $\begin{array}{l}2.8 \\
2.2\end{array}$ & $\begin{array}{r}23.4 \\
9.8\end{array}$ & $\begin{array}{r}52.4 \\
9.2\end{array}$ & $\begin{array}{r}13.4 \\
5.0\end{array}$ \\
\hline RLrP... & $\begin{array}{l}\text { Tops............... } \\
\text { Roots........... }\end{array}$ & $\begin{array}{l}2510 \\
2580\end{array}$ & $\begin{array}{l}54.2 \\
48.8\end{array}$ & $\begin{array}{l}339 \\
305\end{array}$ & $\begin{array}{l}3.0 \\
3.8\end{array}$ & $\begin{array}{r}12.4 \\
9.2\end{array}$ & $\begin{array}{r}46.8 \\
9.2\end{array}$ & $\begin{array}{r}11.8 \\
5.8\end{array}$ \\
\hline RLrPK. . & $\begin{array}{l}\text { Tops............... } \\
\text { Roots........ }\end{array}$ & $\begin{array}{ll}2 & 100 \\
2 & 380\end{array}$ & $\begin{array}{l}46.4 \\
49.2\end{array}$ & $\begin{array}{l}290 \\
308\end{array}$ & $\begin{array}{l}3.0 \\
4.0\end{array}$ & $\begin{array}{l}23.4 \\
14.4\end{array}$ & $\begin{array}{l}53.6 \\
15.2\end{array}$ & $\begin{array}{l}9.6 \\
5.8\end{array}$ \\
\hline \multicolumn{9}{|c|}{ Kewanee, May 16, 1938} \\
\hline None. . & $\begin{array}{l}\text { Leaves........... } \\
\text { Stems.......... }\end{array}$ & $\begin{array}{ll}1 & 200 \\
1 & 450\end{array}$ & $\begin{array}{l}58.4 \\
39.6\end{array}$ & $\begin{array}{l}365 \\
248\end{array}$ & $\begin{array}{l}4.0 \\
3.0\end{array}$ & $\begin{array}{l}39.2 \\
48.2\end{array}$ & $\begin{array}{l}36.8 \\
24.0\end{array}$ & $\begin{array}{l}9.8 \\
8.0\end{array}$ \\
\hline Manure.......... & $\begin{array}{l}\text { Leaves............ } \\
\text { Stems......... }\end{array}$ & $\begin{array}{l}1.040 \\
1880\end{array}$ & $\begin{array}{l}65.6 \\
40.4\end{array}$ & $\begin{array}{l}410 \\
252\end{array}$ & $\begin{array}{l}4.0 \\
3.2\end{array}$ & $\begin{array}{l}47.0 \\
54.0\end{array}$ & $\begin{array}{l}32.8 \\
18.8\end{array}$ & $\begin{array}{l}8.0 \\
7.0\end{array}$ \\
\hline ML. . & $\begin{array}{l}\text { Leaves............. } \\
\text { Stems......... }\end{array}$ & $\begin{array}{ll}1 & 570 \\
3 & 160\end{array}$ & $\begin{array}{l}74.8 \\
49.2\end{array}$ & $\begin{array}{l}468 \\
308\end{array}$ & $\begin{array}{l}4.0 \\
3.2\end{array}$ & $\begin{array}{l}44.4 \\
54.8\end{array}$ & $\begin{array}{l}33.6 \\
19.6\end{array}$ & $\begin{array}{l}9.2 \\
9.4\end{array}$ \\
\hline MLrP. & $\begin{array}{l}\text { Leaves........... } \\
\text { Stems.......... }\end{array}$ & $\begin{array}{ll}2 & 220 \\
3 & 070\end{array}$ & $\begin{array}{l}64.0 \\
51.2\end{array}$ & $\begin{array}{l}400 \\
320\end{array}$ & $\begin{array}{l}5.0 \\
4.0\end{array}$ & $\begin{array}{l}30.6 \\
41.8\end{array}$ & $\begin{array}{l}32.0 \\
24.0\end{array}$ & $\begin{array}{l}8.6 \\
8.6\end{array}$ \\
\hline \multicolumn{9}{|c|}{ Lebanon, October 19, 1937} \\
\hline RL........... & $\begin{array}{l}\text { Tops.............. } \\
\text { Roots.......... }\end{array}$ & $\begin{array}{ll}2 & 100 \\
2 & 160\end{array}$ & $\begin{array}{l}61.2 \\
57.2\end{array}$ & $\begin{array}{l}382 \\
358\end{array}$ & $\begin{array}{l}3.8 \\
3.6\end{array}$ & $\begin{array}{l}35.2 \\
14.4\end{array}$ & $\begin{array}{r}48.0 \\
5.6\end{array}$ & $\begin{array}{r}14.6 \\
7.2\end{array}$ \\
\hline RLrP........ & $\begin{array}{l}\text { Tops.............. } \\
\text { Roots.......... }\end{array}$ & $\begin{array}{ll}2 & 390 \\
2 & 450\end{array}$ & $\begin{array}{l}58.4 \\
43.2\end{array}$ & $\begin{array}{l}365 \\
270\end{array}$ & $\begin{array}{l}4.4 \\
4.8\end{array}$ & $\begin{array}{l}31.2 \\
11.8\end{array}$ & $\begin{array}{r}40.8 \\
8.8\end{array}$ & $\begin{array}{r}11.8 \\
6.6\end{array}$ \\
\hline RLrPK. . . . . . . & $\begin{array}{l}\text { Tops............... } \\
\text { Roots.......... }\end{array}$ & $\begin{array}{ll}2 & 760 \\
3 & 100\end{array}$ & $\begin{array}{l}59.6 \\
50.0\end{array}$ & $\begin{array}{l}372 \\
312\end{array}$ & $\begin{array}{l}4.4 \\
4.8\end{array}$ & $\begin{array}{l}29.4 \\
12.4\end{array}$ & $\begin{array}{r}44.0 \\
8.2\end{array}$ & $\begin{array}{r}13.4 \\
5.6\end{array}$ \\
\hline
\end{tabular}

root growth was evident at the last cutting dates, September 4 and October 19, there was no indication that any considerable amount of nitrogen, phosphorus, or potassium had been transferred from tops to roots (Table 5).

Amounts and composition of leaves and stems. The bulk of leaves in alfalfa hay was smaller than the bulk of stems but contained larger percentages of nitrogen, protein, phosphorus, calcium, and magnesium. Stems contained the larger percentage of potassium (Table 5). 


\section{Red Clover}

Red clover has wide adaptability. It is a desirable legume for various crop rotations and it thrives in mixtures with other legumes and grasses. It is of proved value for soil-improvement purposes. In a corn-oats-clover rotation on the Morrow plots red clover has maintained a much higher level of total nitrogen in the soil than the cornoats rotation has maintained on adjoining land. Under the corn-oatsclover rotation, surface soil contained 3,800 pounds of nitrogen an acre and under the corn-oats rotation, only 3,300 pounds an acre. Corn yields were much higher where red clover was used in the rotation, as was also the protein content of the grain. Both the first and second cuttings of the clover have been removed from the land during the many years of operation.

Because of its high percentages of protein and minerals, red clover stands next to alfalfa for hay and forage (Table 1), and in Illinois is probably more widely used. Red-clover hay averaged lower than alfalfa hay in protein and minerals. No doubt both crops had a higher protein content at an earlier stage of growth than they had at the time of sampling. The fact that the first cutting of alfalfa was made at a slightly earlier stage of maturity than the first cutting of red clover does not alter the significance of the average composition at hay stage.

No great differences were apparent in the protein content of redclover hay that was grown on soils of various productivity levels (Tables 6 and 7). The soil. of the Elizabethtown field - a soil that contained only 840 pounds of nitrogen per acre - produced red-clover hay that was as high in protein as the red-clover hay that was grown on the more fertile and more productive soil of the Joliet field. In some of the tests on these fields the various phosphate applications increased the yield of hay and the protein and phosphorus in the hay.

Table 6. - COMPOSITION OF SOILS:" Treated and Untreated on Five Experiment Fields and One Farm

\begin{tabular}{|c|c|c|c|c|c|c|c|}
\hline \multirow{2}{*}{ Field and farm } & \multirow{2}{*}{ Soil treatment } & $\mathrm{pH}$ & $\mathbf{N}$ & $\mathrm{P}$ & $\mathrm{K}$ & $\mathrm{Ca}$ & $\mathrm{Mg}$ \\
\hline & & \multicolumn{6}{|c|}{ Pounds per acre } \\
\hline Elizabethtown.......... & None............ & 4.5 & 840 & 12 & 210 & 2020 & 530 \\
\hline Joliet... . . . . . . . . . . . . & None............ & 5.2 & 4800 & 15 & 190 & 5640 & 1050 \\
\hline Morrow plots........... & $\begin{array}{l}\text { None } . . . \ldots \ldots \ldots \ldots \\
\text { MLbP } . . \ldots \ldots\end{array}$ & $\begin{array}{l}4.4 \\
5.3\end{array}$ & $\begin{array}{l}3800 \\
4520\end{array}$ & $\begin{array}{r}20 \\
150\end{array}$ & $\begin{array}{l}250 \\
400\end{array}$ & $\begin{array}{l}3920 \\
8080\end{array}$ & $\begin{array}{r}640 \\
1010\end{array}$ \\
\hline Raleigh.............. & RL............. & 6.5 & 2920 & 20 & 100 & 4040 & 480 \\
\hline West Salem. . . . . . . . . . & RL............. & 6.2 & 1900 & 18 & 80 & 2040 & 340 \\
\hline Mulvaney farm.......... & None............. & 5.4 & 3900 & 30 & 260 & $\therefore \ldots$ & $\ldots$ \\
\hline
\end{tabular}

- Topsoil, about 7 inches. 
Table 7. - RED-CLOVER HAY: Yield and Chemical Composition When Grown on Soils of Different Levels of Productivity Under Different Soil Treatments

\begin{tabular}{|c|c|c|c|c|c|c|c|c|c|}
\hline \multirow{2}{*}{ Soil treatment } & \multirow{2}{*}{$\underset{\text { lb./A }}{\text { Hay }}$} & $\mathbf{N}$ & Protein & $\mathbf{P}$ & K & $\mathrm{Ca}$ & $\mathrm{Mg}$ & $\mathrm{Fe}$ & $\mathrm{Mn}$ \\
\hline & & \multicolumn{8}{|c|}{ Pounds per ton of hay } \\
\hline \multicolumn{10}{|c|}{ Elizabethtown } \\
\hline \multicolumn{10}{|c|}{ June, 1943} \\
\hline 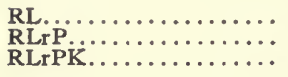 & $\begin{array}{ll}2 & 300 \\
4 & 430 \\
4 & 520\end{array}$ & $\begin{array}{l}55.6 \\
52.8 \\
53.2\end{array}$ & $\begin{array}{l}348 \\
330 \\
332\end{array}$ & $\begin{array}{l}2.6 \\
3.4 \\
3.4\end{array}$ & $\begin{array}{l}47.0 \\
38.0 \\
48.8\end{array}$ & $\begin{array}{l}32.4 \\
32.8 \\
28.0\end{array}$ & $\begin{array}{l}6.4 \\
6.8 \\
5.4\end{array}$ & $\begin{array}{l}.46 \\
.46 \\
.38\end{array}$ & $\begin{array}{l}.12 \\
.05 \\
.06\end{array}$ \\
\hline \multicolumn{10}{|c|}{ August, 1943} \\
\hline 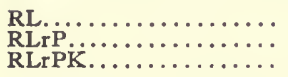 & $\begin{array}{ll}1 & 030 \\
1 & 870 \\
1 & 730\end{array}$ & $\begin{array}{l}45.6 \\
55.2 \\
54.4\end{array}$ & $\begin{array}{l}285 \\
345 \\
340\end{array}$ & $\begin{array}{l}2.6 \\
3.8 \\
3.4\end{array}$ & $\begin{array}{l}31.2 \\
31.2 \\
38.4\end{array}$ & $\begin{array}{l}25.6 \\
24.0 \\
22.4\end{array}$ & $\begin{array}{l}6.8 \\
8.0 \\
6.8\end{array}$ & $\begin{array}{l}.34 \\
.16 \\
.24\end{array}$ & $\begin{array}{l}.08 \\
.05 \\
.09\end{array}$ \\
\hline \multicolumn{10}{|c|}{ Joliet } \\
\hline \multicolumn{10}{|c|}{ June, 1942} \\
\hline 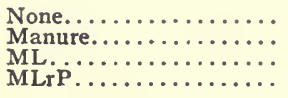 & $\begin{array}{ll}1 & 200 \\
1 & 760 \\
1 & 880 \\
4 & 280\end{array}$ & $\begin{array}{l}52.4 \\
57.2 \\
48.0 \\
52.0\end{array}$ & $\begin{array}{l}328 \\
358 \\
300 \\
325\end{array}$ & $\begin{array}{l}2.4 \\
2.6 \\
1.8 \\
3.0\end{array}$ & $\begin{array}{l}28.6 \\
33.2 \\
30.6 \\
26.6\end{array}$ & $\begin{array}{l}36.8 \\
37.6 \\
33.6 \\
35.2\end{array}$ & $\begin{array}{l}9.4 \\
9.8 \\
6.4 \\
7.0\end{array}$ & $\begin{array}{l}.28 \\
.46 \\
.16 \\
.18\end{array}$ & $\begin{array}{l}.10 \\
.11 \\
.07 \\
.07\end{array}$ \\
\hline \multicolumn{10}{|c|}{ June, 1943} \\
\hline 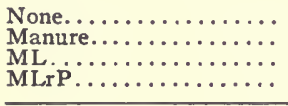 & $\begin{array}{ll}1 & 660 \\
3 & 080 \\
5 & 140 \\
4 & 600\end{array}$ & $\begin{array}{l}57.2 \\
58.0 \\
56.4 \\
58.0\end{array}$ & $\begin{array}{l}358 \\
362 \\
352 \\
362\end{array}$ & $\begin{array}{l}3.2 \\
3.2 \\
3.2 \\
5.6\end{array}$ & $\begin{array}{l}38.4 \\
43.6 \\
43.0 \\
29.4\end{array}$ & $\begin{array}{l}34.4 \\
31.6 \\
29.6 \\
36.8 \\
\end{array}$ & $\begin{array}{r}9.8 \\
8.0 \\
7.8 \\
11.4\end{array}$ & $\begin{array}{l}.20 \\
.22 \\
.32 \\
.36 \\
\end{array}$ & $\begin{array}{l}.13 \\
.15 \\
.05 \\
.06\end{array}$ \\
\hline \multicolumn{10}{|c|}{ Morrow plots } \\
\hline \multicolumn{10}{|c|}{ June, 1939} \\
\hline 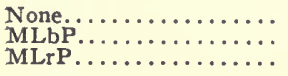 & $\begin{array}{ll}1 & 380 \\
2 & 780 \\
2 & 780\end{array}$ & $\begin{array}{l}50.0 \\
46.8 \\
48.8\end{array}$ & $\begin{array}{l}312 \\
292 \\
305\end{array}$ & $\begin{array}{l}3.0 \\
3.6 \\
3.6\end{array}$ & $\begin{array}{l}16.2 \\
14.4 \\
15.0\end{array}$ & $\begin{array}{l}27.6 \\
37.2 \\
36.0\end{array}$ & $\begin{array}{r}8.4 \\
10.2 \\
9.6\end{array}$ & $\begin{array}{l}.50 \\
.76 \\
.90\end{array}$ & $\begin{array}{l}.14 \\
.13 \\
.15\end{array}$ \\
\hline \multicolumn{10}{|c|}{ June, 1942} \\
\hline 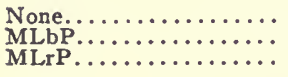 & $\begin{array}{lr} & 980 \\
4 & 640 \\
3 & 820\end{array}$ & $\begin{array}{l}57.6 \\
48.4 \\
50.4\end{array}$ & $\begin{array}{l}360 \\
302 \\
315\end{array}$ & $\begin{array}{l}2.2 \\
3.0 \\
3.2\end{array}$ & $\begin{array}{l}30.6 \\
36.0 \\
36.0\end{array}$ & $\begin{array}{l}33.2 \\
34.8 \\
36.4\end{array}$ & $\begin{array}{l}7.4 \\
5.2 \\
7.0\end{array}$ & $\begin{array}{l}.12 \\
.08 \\
.18\end{array}$ & $\begin{array}{l}.16 \\
.07 \\
.07\end{array}$ \\
\hline \multicolumn{10}{|c|}{ August, 1942} \\
\hline $\begin{array}{l}\text { None } \ldots \ldots \ldots \ldots \ldots \ldots \ldots \\
\text { MLbP } \ldots \ldots \ldots \ldots \ldots \ldots \ldots \\
\text { MLrP...... }\end{array}$ & $\begin{array}{ll}1 & 800 \\
2 & 380 \\
2 & 480\end{array}$ & $\begin{array}{l}48.8 \\
48.8 \\
50.0\end{array}$ & $\begin{array}{l}305 \\
305 \\
312\end{array}$ & $\begin{array}{l}2.4 \\
3.4 \\
4.2\end{array}$ & $\begin{array}{l}37.2 \\
37.2 \\
40.4\end{array}$ & $\begin{array}{l}26.8 \\
25.6 \\
27.2\end{array}$ & $\begin{array}{l}6.4 \\
6.4 \\
6.2\end{array}$ & $\begin{array}{l}.32 \\
.14 \\
.50\end{array}$ & $\begin{array}{l}.12 \\
.06 \\
.06\end{array}$ \\
\hline \multicolumn{10}{|c|}{ Raleigh, June, 1935} \\
\hline 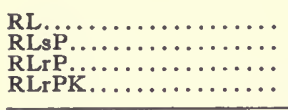 & $\begin{array}{l}\ldots \cdots \\
\cdots \cdots \\
\cdots \cdots\end{array}$ & $\begin{array}{l}39.4 \\
51.2 \\
48.8 \\
50.0\end{array}$ & $\begin{array}{l}246 \\
320 \\
305 \\
312\end{array}$ & $\begin{array}{l}2.7 \\
4.2 \\
4.0 \\
4.2\end{array}$ & $\begin{array}{l}18.2 \\
14.6 \\
13.4 \\
18.5\end{array}$ & $\begin{array}{l}25.4 \\
34.2 \\
33.4 \\
31.8\end{array}$ & $\begin{array}{l}10.7 \\
13.5 \\
12.3 \\
10.7\end{array}$ & $\begin{array}{l}\cdots \\
\cdots \\
\cdots\end{array}$ & $\begin{array}{l}\cdots \\
\cdots \\
\cdots\end{array}$ \\
\hline \multicolumn{10}{|c|}{ West Salem, June, 1935} \\
\hline 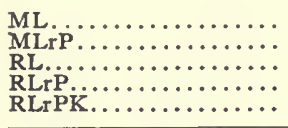 & $\begin{array}{l}\ldots \cdots \\
\cdots \cdots \\
\cdots \cdots \\
\cdots \cdots\end{array}$ & $\begin{array}{l}41.6 \\
42.4 \\
41.2 \\
47.2 \\
39.6\end{array}$ & $\begin{array}{l}260 \\
265 \\
258 \\
295 \\
248\end{array}$ & $\begin{array}{l}2.4 \\
3.4 \\
2.8 \\
4.0 \\
3.2\end{array}$ & $\begin{array}{l}25.8 \\
21.8 \\
17.0 \\
11.4 \\
17.0\end{array}$ & $\begin{array}{l}21.2 \\
19.4 \\
26.2 \\
25.4 \\
22.2\end{array}$ & $\begin{array}{r}11.2 \\
8.2 \\
14.8 \\
16.2 \\
11.8\end{array}$ & $\begin{array}{l}\cdots \\
\cdots \\
\cdots \\
\cdots\end{array}$ & $\begin{array}{l}\cdots \\
\cdots \\
\cdots \\
\cdots\end{array}$ \\
\hline \multicolumn{10}{|c|}{ Mulvaney farm, June, 1938} \\
\hline $\begin{array}{l}\text { None. } \because, 230 \text { pounds..... } \\
\text { Fused } \mathrm{P}, 250 \text { pounds..... } \\
\text { Super } \mathbf{P}, 2500 \text { pounds.... } \\
\text { Rock P, } 1000 \text {. }\end{array}$ & $\begin{array}{ll}5 & 480 \\
9 & 380 \\
7 & 270 \\
9 & 360\end{array}$ & $\begin{array}{l}44.8 \\
47.2 \\
45.6 \\
49.2\end{array}$ & $\begin{array}{l}280 \\
295 \\
285 \\
307\end{array}$ & $\begin{array}{l}2.8 \\
3.8 \\
3.4 \\
4.4\end{array}$ & $\begin{array}{l}45.0 \\
40.0 \\
42.4 \\
42.4\end{array}$ & $\begin{array}{l}26.8 \\
26.0 \\
28.0 \\
32.0\end{array}$ & $\begin{array}{r}7.0 \\
8.0 \\
9.4 \\
11.2\end{array}$ & $\begin{array}{l}.22 \\
.42 \\
.24 \\
.36\end{array}$ & $\begin{array}{l}.18 \\
.10 \\
.10 \\
.13\end{array}$ \\
\hline
\end{tabular}


The phosphorus content of some of the red-clover hay was extremely low mainly because of phosphorus deficiencies in the soils where it was grown and partly because of seasonal conditions. The phosphorus content of the hay increased substantially when any one of the various phosphate fertilizers was applied.

The composition of the red-clover hay from the Joliet field (Table 7) showed the effect of seasonal variation. The season was relatively dry during May, 1942, but an unusually heavy rainfall occurred during May, 1943. This rainfall increased the acre yield of the hay and also the amounts of nitrogen, protein, phosphorus, and potassium in it.

Recovery of phosphorus by red clover from the three phosphates used on the Mulvaney farm was as follows: fused phosphate, 10.1 pounds an acre, or 29.8 percent of the amount applied; superphosphate, 4.7 pounds, or 21.3 percent of the amount applied; rock phosphate, 12.9 pounds, or 10.8 percent of the amount applied. These percentages may be taken to represent the relative availability of the three forms of phosphorus used (Table 7). The phosphates were applied the previous year ahead of oat seeding. The red clover was seeded in the oats.

\section{Korean Lespedeza}

Lespedeza has recently become important as a hay and pasture crop. It is valuable too as a seed crop and is to some extent desirable for soil improvement. The Korean variety is used generally and in many respects has proved satisfactory. Judged by its protein and minerals, lespedeza hay has a high feeding value, altho it averages lower in these nutrients than almost any other legume (Tables 1, 8, and 9).

Lespedeza responds to various soil treatments. The use of limestone, phosphate, and potash greatly increases the yield of hay and also its protein content and mineral content. The phosphorus content of lespedeza hay is very low even on phosphated land. The reason probably is that lespedeza makes most of its growth during the dry parts of the season. Lespedeza had a much lower content of calcium and magnesium than any of the other legumes listed in Table 1.

Composition of leaves, stems, and roots. In lespedeza the leaves make up the largest amounts of protein and minerals. For this reason any considerable loss of leaves in harvesting and curing the hay will greatly impair its feeding value. The stems contain about half as much protein and minerals as the leaves and are doubtless less palatable. The root growth is relatively small and in no way compares with the root system of alfalfa and sweet clover (Table 9). 
Table 8. - KOREAN LESPEDEZA HAY: Yield and Chemical Composition on Different Fields Under Different Soil Treatments

\begin{tabular}{|c|c|c|c|c|c|c|c|}
\hline \multirow{2}{*}{ Soil treatment } & \multirow{2}{*}{$\underset{\text { lb./A }}{\text { Hay }}$} & $\mathbf{N}$ & Protein & $\mathbf{P}$ & $\mathbf{K}$ & $\mathrm{Ca}$ & $\mathbf{M g}$ \\
\hline & & \multicolumn{6}{|c|}{ Pounds per ton of hay } \\
\hline \multicolumn{8}{|c|}{ Elizabethtown, September 8, 1943} \\
\hline \multicolumn{8}{|c|}{ Ewing } \\
\hline \multicolumn{8}{|c|}{ September 3, 1942} \\
\hline 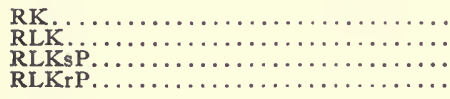 & $\begin{array}{ll}1 & 540 \\
3 & 580 \\
3 & 680 \\
3 & 730\end{array}$ & $\begin{array}{l}36.0 \\
43.2 \\
39.6 \\
43.6\end{array}$ & $\begin{array}{l}225 \\
282 \\
248 \\
285\end{array}$ & $\begin{array}{l}2.0 \\
2.0 \\
2.2 \\
2.2\end{array}$ & $\begin{array}{l}24.8 \\
26.8 \\
25 \cdot 4 \\
24.8\end{array}$ & $\begin{array}{l}14.0 \\
18.0 \\
16.4 \\
16.0\end{array}$ & $\begin{array}{l}6.0 \\
5.4 \\
5 \cdot 2 \\
5.4\end{array}$ \\
\hline \multicolumn{8}{|c|}{ September 22, 1943} \\
\hline 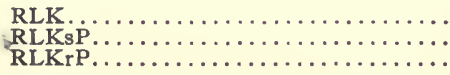 & $\begin{array}{l}\cdots \cdots \\
\cdots \cdots \\
\cdots \cdots\end{array}$ & $\begin{array}{l}37.6 \\
38.8 \\
41.8\end{array}$ & $\begin{array}{l}235 \\
242 \\
261\end{array}$ & $\begin{array}{l}2.2 \\
2.4 \\
2.8\end{array}$ & $\begin{array}{l}16.2 \\
18.2 \\
19.6\end{array}$ & $\begin{array}{l}17.2 \\
19.6 \\
18.0\end{array}$ & $\begin{array}{l}4.2 \\
4.2 \\
4.6\end{array}$ \\
\hline
\end{tabular}

Newton, September 20, 1943

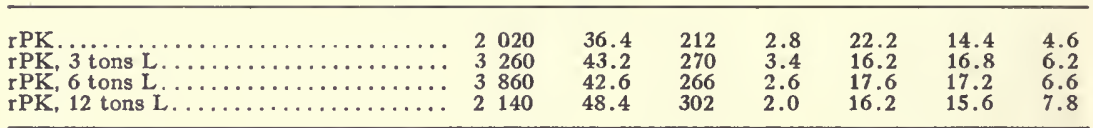

Sparta, September 9, 1943

\begin{tabular}{|c|c|c|c|c|c|c|c|}
\hline 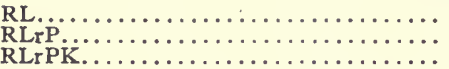 & $\begin{array}{l}\cdots \cdots \\
\cdots \cdots \\
\cdots \cdots\end{array}$ & $\begin{array}{l}47.2 \\
50 \cdot 0 \\
45.2\end{array}$ & $\begin{array}{l}295 \\
312 \\
282\end{array}$ & $\begin{array}{l}2.4 \\
3.2 \\
3.0\end{array}$ & $\begin{array}{l}16.2 \\
16.2 \\
20.2\end{array}$ & $\begin{array}{l}20.0 \\
20.8 \\
20.4\end{array}$ & $\begin{array}{l}7.6 \\
7.0 \\
6.6\end{array}$ \\
\hline
\end{tabular}

West Salem, September 20, 1934

\begin{tabular}{|c|c|c|c|c|c|c|c|}
\hline 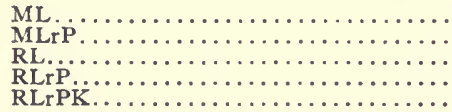 & $\begin{array}{ll}4 & 360 \\
4 & 310 \\
3 & 400 \\
3 & 980 \\
3 & 040\end{array}$ & $\begin{array}{l}44.0 \\
44.6 \\
36.0 \\
43.4 \\
46.8\end{array}$ & $\begin{array}{l}275 \\
279 \\
225 \\
271 \\
292\end{array}$ & $\begin{array}{l}4.2 \\
5.4 \\
2.8 \\
5.0 \\
6.6\end{array}$ & $\begin{array}{l}21.8 \\
21.8 \\
13.6 \\
12.2 \\
16.2\end{array}$ & $\begin{array}{l}14.8 \\
16.6 \\
16.4 \\
16.8 \\
17.2\end{array}$ & $\begin{array}{l}4.4 \\
5.0 \\
6.4 \\
7.0 \\
6.8\end{array}$ \\
\hline
\end{tabular}




\section{Table 9. - KOREAN LESPEDEZA LEAVES, STEMS, ROOTS: Yield and Chemical Composition}

(Samples from two fields)

\begin{tabular}{|c|c|c|c|c|c|c|c|c|}
\hline 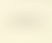 & \multirow{2}{*}{ Part of plant } & \multirow{2}{*}{$\underset{\text { matter }}{\text { Drb./A }}$} & $\mathbf{N}$ & Protein & $\mathbf{P}$ & $\mathrm{K}$ & $\mathrm{Ca}$ & $\mathrm{Mg}$ \\
\hline & & & \multicolumn{6}{|c|}{ Pounds per ton of crop } \\
\hline
\end{tabular}

Aledo," October 11, 1935

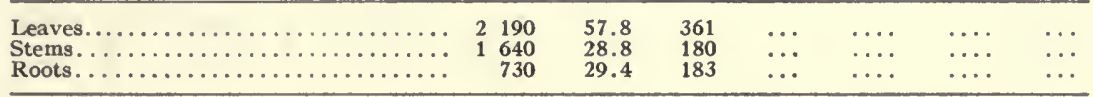

West Salem,b September 20, 1934

\begin{tabular}{|c|c|c|c|c|c|c|c|}
\hline 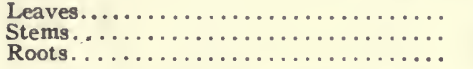 & $\begin{array}{l}1960 \\
1920 \\
790\end{array}$ & $\begin{array}{l}55.9 \\
23.5 \\
30.3\end{array}$ & $\begin{array}{l}349 \\
147 \\
189\end{array}$ & $\begin{array}{l}6.3 \\
3.3 \\
2.5\end{array}$ & $\begin{array}{r}19.2 \\
11.0 \\
8.5\end{array}$ & $\begin{array}{r}24.9 \\
9.0 \\
10.9\end{array}$ & $\begin{array}{l}8.6 \\
4.7 \\
6.5\end{array}$ \\
\hline
\end{tabular}

- Soil on the Aledo field was untreated.

b Three plots of lespedeza were grown under separate treatments, ML, RLP, and RLPK. Averages are of the three plots.

\section{Sweet Clover}

Sweet clover is one of the general utility plants on farms. It is an excellent green manure. It can be harvested for hay or seed and it makes good pasture. In order to estimate the value of sweet clover for its various uses it is desirable to know the composition of the roots and tops at several stages of growth. Sweet clover is widely adapted to different climates but must have a favorable soil condition.

Sweet clover as green manure. The heavy root system and luxuriant top growth of sweet clover can add large amounts of nitrogenous organic matter to soils. Roots and tops sometimes produce as high as 5 to 6 tons of dry material an acre and have contained as high as 150 to 240 pounds of total nitrogen in this growth. Since about two-thirds of this nitrogen is fixed from the atmosphere, there is under these conditions considerable gain to the soil from a growth of sweet clover (Tables 10, 11, and 12).

Sweet clover grown on the light-colored Cisne silt loam in southern Illinois contained considerably less nitrogen than sweet clover grown on the more fertile soils of central and northern Illinois. On the DuBois field (Cisne silt loam) the maximum growth of sweet clover at the full-bloom stage was slightly over 6 tons an acre of roots and tops, and this growth contained about 150 pounds of total nitrogen. On the Spring Valley field the maximum growth at fullbloom stage was slightly over 5 tons an acre and contained about 240 pounds of nitrogen (Tables 10,11, 12, and 13). 
Table 10. - SWEET-CLOVER TOPS AND ROOTS: Yield and Chemical Composition at Different Harvest Dates

(Carthage field, averages of three years, roots taken to a depth of approximately 36 inches)

\begin{tabular}{lllllll}
\hline \hline Part of plant & Dry & $\mathrm{N}$ & $\mathrm{P}$ & $\mathrm{K}$ & $\mathrm{Ca}$ & $\mathrm{Mg}$ \\
\cline { 3 - 5 } & & & \multicolumn{2}{c}{ Pounds per acre } \\
\hline
\end{tabular}

Not fall-cut: fall growth, November 13-28

\begin{tabular}{|c|c|c|c|c|c|c|}
\hline 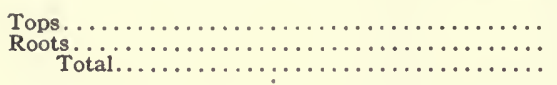 & $\begin{array}{ll}1 & 720 \\
3 & 750 \\
5 & 470\end{array}$ & $\begin{array}{r}25.2 \\
141.9 \\
167.1\end{array}$ & $\begin{array}{r}1.6 \\
11.7 \\
13.3\end{array}$ & $\begin{array}{l}13.0 \\
41.0 \\
54.0\end{array}$ & $\begin{array}{r}13.1 \\
4.9 \\
18.0\end{array}$ & $\begin{array}{r}9.2 \\
9.6 \\
18.8\end{array}$ \\
\hline \multicolumn{7}{|c|}{ Not fall-cut: spring growth, April 13-18 } \\
\hline 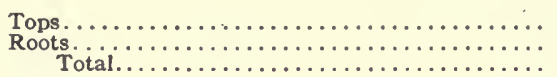 & $\begin{array}{ll}960 \\
1 & 740 \\
2 & 700\end{array}$ & $\begin{array}{r}46.3 \\
83.5 \\
129.8\end{array}$ & $\begin{array}{l}3.2 \\
4.8 \\
8.0\end{array}$ & $\begin{array}{l}17.7 \\
10.5 \\
28.2\end{array}$ & $\begin{array}{r}9.6 \\
4.7 \\
14.3\end{array}$ & $\begin{array}{l}4.8 \\
4.8 \\
9.6\end{array}$ \\
\hline
\end{tabular}

Early fall-cut: fall growth, November 13-28

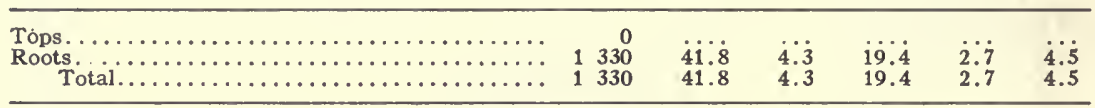

Early fall-cut: spring growth, April 13-18

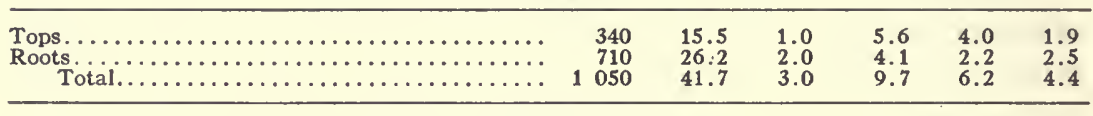

Late fall-cut: fall growth, November 13-28

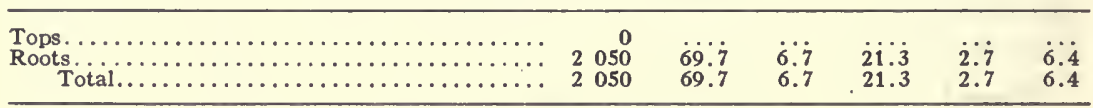

Late fall-cut: spring growth, April 13-18

\begin{tabular}{|c|c|c|c|c|c|c|c|}
\hline 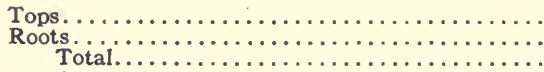 & $\begin{array}{l}1 \\
1\end{array}$ & $\begin{array}{l}560 \\
120 \\
680\end{array}$ & $\begin{array}{l}25.4 \\
46.9 \\
72.3\end{array}$ & $\begin{array}{l}1.9 \\
3.4 \\
5.3\end{array}$ & $\begin{array}{r}8.6 \\
7.0 \\
15.6\end{array}$ & $\begin{array}{l}6.6 \\
3.3 \\
9.9\end{array}$ & $\begin{array}{l}3.1 \\
3.9 \\
7.0\end{array}$ \\
\hline
\end{tabular}

Table 11. - SWEET-CLOVER TOPS AND ROOTS: Dry-Matter Yields and Nitrogen Content at Different Stages of Growth

(Spring Valley field, averages of two years, roots taken to a depth of approximately 40 inches)

\begin{tabular}{|c|c|c|c|c|c|c|}
\hline \multirow{3}{*}{ Date of sampling } & \multicolumn{3}{|c|}{ Dry matter } & \multicolumn{3}{|c|}{ Nitrogen } \\
\hline & Tops & Roots & Total & Tops & Roots & Total \\
\hline & \multicolumn{3}{|c|}{ Pounds per acre } & \multicolumn{3}{|c|}{ Pounds per acre } \\
\hline 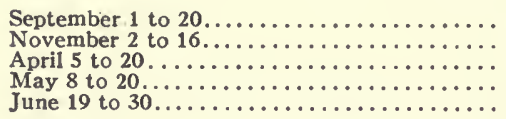 & $\begin{array}{ll}2 & 070 \\
2 & 410 \\
& 290 \\
2 & 730 \\
8 & 500\end{array}$ & $\begin{array}{ll}1 & 370 \\
3 & 390 \\
3 & 770 \\
2 & 540 \\
1 & 850\end{array}$ & $\begin{array}{rr}3 & 440 \\
5 & 800 \\
4 & 060 \\
5 & 270 \\
10 & 350\end{array}$ & $\begin{array}{r}70 \\
50 \\
17 \\
110 \\
200\end{array}$ & $\begin{array}{r}49 \\
167 \\
176 \\
90 \\
39\end{array}$ & $\begin{array}{l}119 \\
217 \\
193 \\
200 \\
239\end{array}$ \\
\hline
\end{tabular}


Table 12. - SWEET-CLOVER TOPS AND ROOTS: Amounts of Dry Matter, Nitrogen, Phosphorus, and Potassium at Different Stages of Growth and Under Different Soil Treatments

(DuBois field, all roots taken to a depth of approximately 12 inches)

\begin{tabular}{|c|c|c|c|c|c|c|}
\hline \multirow{3}{*}{ Date of sampling } & \multicolumn{3}{|c|}{ Dry matter } & \multirow{2}{*}{$\mathbf{N}$} & \multirow{2}{*}{$\mathbf{P}$} & \multirow{2}{*}{$\mathbf{K}$} \\
\hline & Tops & Roots & Total & & & \\
\hline & \multicolumn{3}{|c|}{ Pounds per acre } & \multicolumn{3}{|c|}{ Pounds per acre } \\
\hline \multicolumn{7}{|c|}{ Lime and bPK applied } \\
\hline 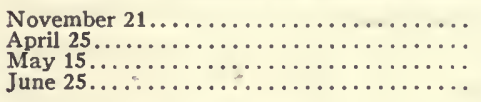 & $\begin{array}{rr} & 940 \\
1 & 490 \\
4 & 200 \\
10 & 150\end{array}$ & $\begin{array}{ll}1 & 540 \\
1 & 080 \\
1 & 580 \\
2 & 280\end{array}$ & $\begin{array}{rr}2 & 480 \\
2 & 570 \\
5 & 780 \\
12 & 430\end{array}$ & $\begin{array}{r}67.0 \\
78.7 \\
147.7 \\
148.9\end{array}$ & $\begin{array}{r}9.1 \\
8.6 \\
21.8 \\
27.9\end{array}$ & $\begin{array}{r}11.3 \\
24.6 \\
81.1 \\
123.4\end{array}$ \\
\hline \multicolumn{7}{|c|}{ Lime applied } \\
\hline 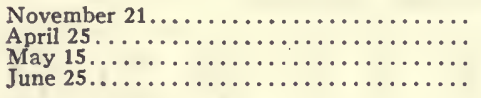 & $\begin{array}{rr} & 370 \\
& 530 \\
1 & 490 \\
5 & 640\end{array}$ & $\begin{array}{r}690 \\
480 \\
630 \\
1460\end{array}$ & $\begin{array}{ll}1 & 060 \\
1 & 010 \\
2 & 120 \\
7 & 100\end{array}$ & $\begin{array}{l}26.3 \\
25.3 \\
53.3 \\
90.3\end{array}$ & $\begin{array}{l}2.2 \\
1.5 \\
2.7 \\
6.0\end{array}$ & $\begin{array}{r}4.7 \\
6.1 \\
15.0 \\
34.0\end{array}$ \\
\hline
\end{tabular}

Table 13. - SWEET-CLOVER TOPS AND ROOTS: Dry-Matter Yields and Percentages of Nitrogen, Phosphorus, and Potassium at Different Stages of Growth Under Different Soil Treatments

(DuBois field)

\begin{tabular}{|c|c|c|c|c|c|c|c|c|}
\hline \multirow{3}{*}{ Date } & \multicolumn{4}{|c|}{ - Top growth } & \multicolumn{4}{|c|}{ Root growth } \\
\hline & \multirow{2}{*}{$\underset{1 \mathrm{~b} . / \mathrm{A}}{\mathrm{DM}}$} & $\mathrm{N}$ & $\mathbf{P}$ & $\mathbf{K}$ & \multirow{2}{*}{$\underset{\mathrm{lb} . / \mathrm{A}}{\mathrm{DM}}$} & $\mathbf{N}$ & $\mathbf{P}$ & $\mathbf{K}$ \\
\hline & & \multicolumn{3}{|c|}{ Percent } & & \multicolumn{3}{|c|}{ Percent } \\
\hline 3 & \multicolumn{4}{|c|}{ Lime applied } & & & & \\
\hline 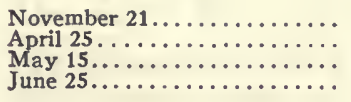 & $\begin{array}{rr} & 370 \\
530 \\
1 & 490 \\
5 & 640\end{array}$ & $\begin{array}{l}1.92 \\
3.09 \\
2.94 \\
1.34\end{array}$ & $\begin{array}{l}.08 \\
.18 \\
.14 \\
.09\end{array}$ & $\begin{array}{l}.47 \\
.91 \\
.90 \\
.52\end{array}$ & $\begin{array}{r}690 \\
480 \\
630 \\
1460\end{array}$ & $\begin{array}{l}2.78 \\
1.85 \\
1.51 \\
1.01\end{array}$ & $\begin{array}{l}.28 \\
.11 \\
.10 \\
.06\end{array}$ & $\begin{array}{l}.44 \\
.28 \\
.25 \\
.32\end{array}$ \\
\hline \multicolumn{9}{|c|}{ Lime and bP applied } \\
\hline 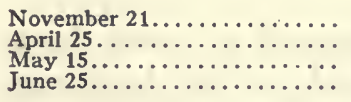 & $\begin{array}{ll} & 590 \\
1 & 460 \\
3 & 020 \\
5 & 630\end{array}$ & $\begin{array}{l}2.05 \\
3.99 \\
3.10 \\
1.97\end{array}$ & $\begin{array}{l}.08 \\
.35 \\
.41 \\
.26\end{array}$ & $\begin{array}{l}.21 \\
.86 \\
.65 \\
.44\end{array}$ & $\begin{array}{r}900 \\
530 \\
1370 \\
1490\end{array}$ & $\begin{array}{l}3.44 \\
2.40 \\
1.95 \\
1.28\end{array}$ & $\begin{array}{l}.42 \\
.42 \\
.34 \\
.28\end{array}$ & $\begin{array}{l}.42 \\
.25 \\
.12 \\
.09\end{array}$ \\
\hline \multicolumn{9}{|c|}{ Lime and $\mathrm{K}$ applied } \\
\hline $\begin{array}{l}\text { November } 21 \ldots \ldots \ldots \ldots \ldots \ldots \ldots \\
\text { April } 25, \ldots \ldots \ldots \ldots \ldots \ldots \ldots \\
\text { May } 15, \ldots \ldots \ldots \ldots \ldots \ldots \\
\text { June } 25 \ldots \ldots \ldots \ldots \ldots\end{array}$ & $\begin{array}{rr} & 340 \\
& 770 \\
2 & 730 \\
5 & 280\end{array}$ & $\begin{array}{l}1.91 \\
3.34 \\
2.65 \\
1.49\end{array}$ & $\begin{array}{l}.07 \\
.18 \\
.13 \\
.10\end{array}$ & $\begin{array}{l}.72 \\
1.55 \\
1.52 \\
1.11\end{array}$ & $\begin{array}{r}710 \\
550 \\
900 \\
1920\end{array}$ & $\begin{array}{l}3.20 \\
2.14 \\
1.44 \\
1.03\end{array}$ & $\begin{array}{l}.22 \\
.11 \\
.08 \\
.05\end{array}$ & $\begin{array}{l}.60 \\
.69 \\
.65 \\
.36\end{array}$ \\
\hline , & \multicolumn{4}{|c|}{ Lime and bPK applied } & & & & \\
\hline $\begin{array}{l}\text { November } 21 \ldots \ldots \ldots \ldots \ldots \ldots \ldots \\
\text { April } 25 . \ldots \ldots \ldots \ldots \ldots \ldots \ldots \\
\text { May } 15 \ldots \ldots \ldots \ldots \ldots \ldots\end{array}$ & $\begin{array}{rr} & 940 \\
1 & 490 \\
4 & 200 \\
10 & 150\end{array}$ & $\begin{array}{r}1.70 \\
3.48 \\
2.84 \\
.94\end{array}$ & $\begin{array}{l}.07 \\
.33 \\
.40 \\
.19\end{array}$ & $\begin{array}{r}.51 \\
1.38 \\
1.73 \\
.92\end{array}$ & $\begin{array}{ll}1 & 540 \\
1 & 080 \\
1 & 580 \\
2 & 280\end{array}$ & $\begin{array}{l}3.31 \\
2.49 \\
1.80 \\
1.41\end{array}$ & $\begin{array}{l}.55 \\
.36 \\
.32 \\
.19\end{array}$ & $\begin{array}{l}.42 \\
.37 \\
.47 \\
.40\end{array}$ \\
\hline
\end{tabular}


Productivity levels affected the nitrogen and minerals contained in both the roots and the tops of the spring growth of sweet clover (Table 14). The sweet clover produced on the more productive soils had higher percentages of nitrogen and minerals than that produced on the less productive soils.

\section{Table 14. - SWEET-CLOVER TOPS AND ROOTS: Dry-Matter Yields and Chemical Composition in Different Sections of Illinois When Plowed Down for Green Manure}

(Average of samples for two years)

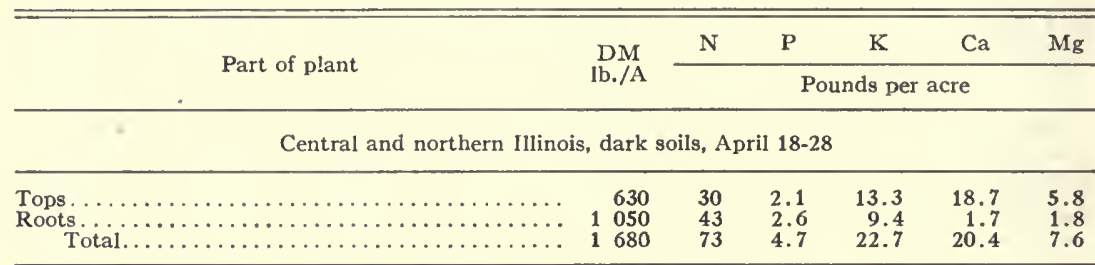

Southern Illinois, light-colored soils, May 7-16

\begin{tabular}{|c|c|c|c|c|c|c|}
\hline 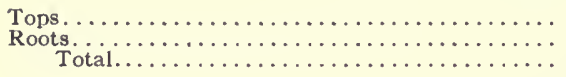 & $\begin{array}{l}1190 \\
470 \\
1660\end{array}$ & $\begin{array}{l}30 \\
10 \\
40\end{array}$ & $\begin{array}{l}3.0 \\
1.0 \\
4.0\end{array}$ & $\begin{array}{r}17.4 \\
3.1 \\
20.5\end{array}$ & $\begin{array}{r}9.4 \\
3.3 \\
12.7\end{array}$ & $\begin{array}{l}3.9 \\
3.5 \\
7.4\end{array}$ \\
\hline
\end{tabular}

Central Illinois, heavy soils, April 17-20

\begin{tabular}{|c|c|c|c|c|c|c|}
\hline 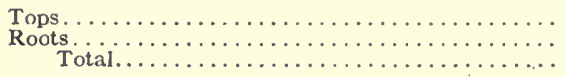 & $\begin{array}{l}810 \\
1000 \\
1810\end{array}$ & $\begin{array}{l}35 \\
43 \\
78\end{array}$ & $\begin{array}{l}2.5 \\
2.4 \\
4.9\end{array}$ & $\begin{array}{r}15.5 \\
8.2 \\
23.7\end{array}$ & $\begin{array}{r}11.4 \\
3.0 \\
14.4\end{array}$ & $\begin{array}{l}5.6 \\
3.9 \\
9.5\end{array}$ \\
\hline
\end{tabular}

Central Illinois, sandy soils, April $\mathbf{1 8}$

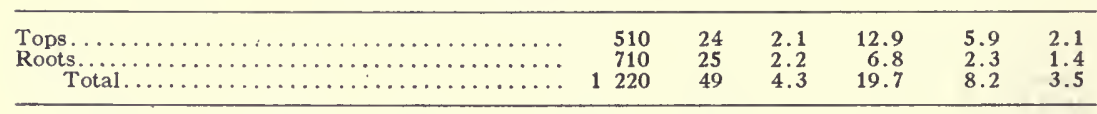

s Central and northern Illinois data are from Clayton, Dixon, Mt. Morris, and Kewanee fields. Southern Illinois data are from Newton. West Salem, Ewing, Raleigh, and Toledo fields. Central Illinois. heavy soils, include the Hartsburg and Minonk fields. Central Illinois, sandy soils, are represented by the Oquawka field.

Sweet clover fall-cut. Removal of the top growth of sweet clover during September and October reduced the yields of the April crop (Table 10), the amounts of the reduction ranging from 1,000 to 1,700 pounds an acre. Fall cutting did not affect the quality (amounts of nitrogen, protein, and minerals) of the spring growth. The biggest difference caused by fall cutting was the reduced yields of roots and tops. Close pasturing in the fall has almost the same effect, as fall cutting.

Composition of leaves and stems. The amounts of leaves and stems were about equally divided in both the October and the April growth of sweet clover. With one exception, the leaves contained more nitro- 
gen and mineral elements than the stems - the stems of the April 24 sampling contained 12 pounds per ton more potassium than did the leaves. Root growth was relatively large on October 23 and relatively small on April 24 because of translocation at these two stages of growth (Table 15).

\section{Table 15. - SWEET-CLOVER LEAVES, STEMS, AND ROOTS:}

Yield and Chemical Composition of Fall and Spring Growths

(Hartsburg field, roots taken to a depth of approximately 7 inches)

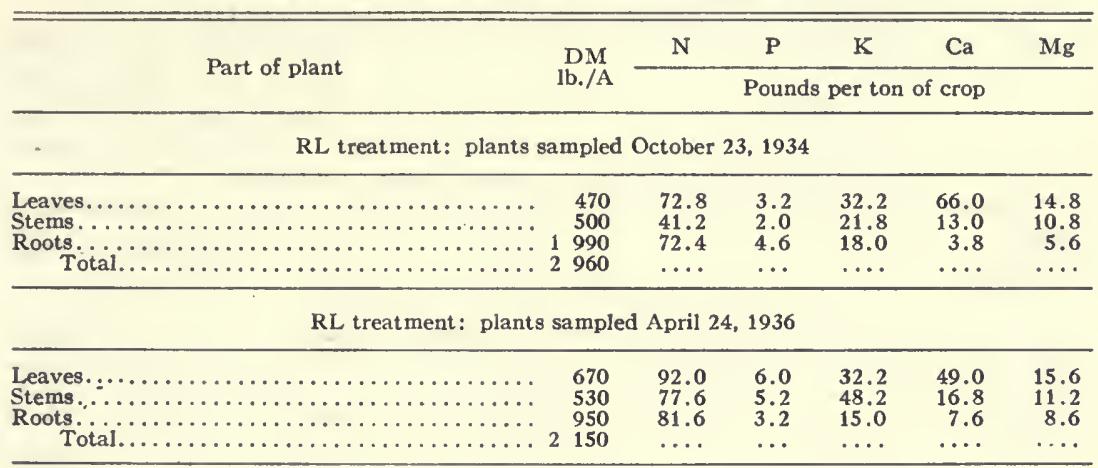

\section{Relative Value of Legumes as Plow-Under Crops}

The relative value of lespedeza, alfalfa, sweet clover, and soybeans for soil improvement or green manure is summarized in Table 16. These data show the amounts of material (dry basis) in the roots and tops at the time when each can best be used as a plow-under crop. Nitrogen, phosphorus, potassium, calcium, and magnesium are presented as pounds per ton so that the amounts of these elements in each crop can be readily compared.

Soybeans had a heavy top growth and a relatively small root growth. The nitrogen content of the tops was relatively high. The roots contained about half as much nitrogen as the tops.

Lespedeza had about the same proportion of roots to tops as did soybeans, but the total yield of lespedeza was considerably lower than that of soybeans. The tops contained less nitrogen (37.8 pounds per ton) than the soybean tops (58.8 pounds per ton).

Alfalfa had a relatively large bulk of roots, and in growth of roots and tops per acre it compared favorably with soybeans. Both roots and tops were relatively high in nitrogen. The roots contained 52.6 pounds of nitrogen per ton and the tops, 57.8 pounds per ton. 
Sweet clover had a relatively small bulk of roots and tops - less than a ton an acre in the spring growth the second year after seeding. The amount of nitrogen per ton of roots and tops was very high on the dark soils (177.2 pounds per ton) but considerably lower on the lightcolored soils (94.2 pounds per ton).

\section{Table 16. - LESPEDEZA, ALFALFA, SWEET CLOVER, AND \\ SOYBEANS: Dry-Matter Yields and Chemical Composition of Tops and Roots in the Topsoil \\ (Averages of a number of years and of several experiment fields)}

\begin{tabular}{|c|c|c|c|c|c|c|c|}
\hline & Port of nlant & DM & $\mathrm{N}$ & $\mathbf{P}$ & $\mathbf{K}$ & $\mathrm{Ca}$ & $\mathrm{Mg}$ \\
\hline$\cdot$ & Part or plant & 1b./A & \multicolumn{5}{|c|}{ Pounds per ton } \\
\hline
\end{tabular}

Southern Illinois, light-colored soils: lespedeza, fall growth

\begin{tabular}{|c|c|c|c|c|c|c|}
\hline 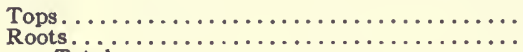 & $\begin{array}{r}330 \\
380\end{array}$ & $\begin{array}{l}37.8 \\
26.4\end{array}$ & $\begin{array}{l}4.8 \\
3.6\end{array}$ & $\begin{array}{l}19.8 \\
15.2\end{array}$ & $\begin{array}{r}20.4 \\
2.0\end{array}$ & $\begin{array}{l}7.2 \\
7.8\end{array}$ \\
\hline 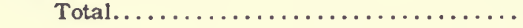 & 2710 & $\ldots$ & $\ldots$ & $\ldots$ & ... & ... \\
\hline
\end{tabular}

Central Illinois, dark soils: alfalfa, hay stage

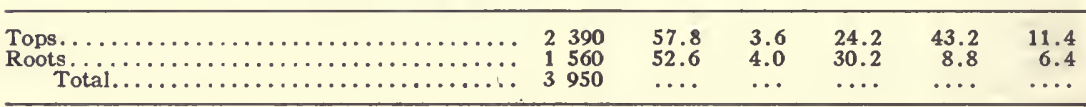

Central and northern Illinois, dark soils: sweet clover, spring growth

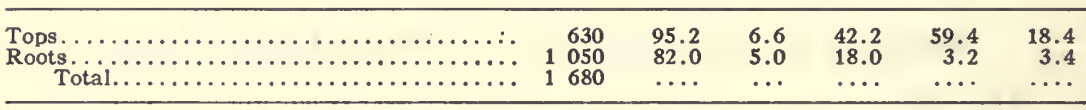

Southern Illinois, light-colored soils: sweet clover, spring growth

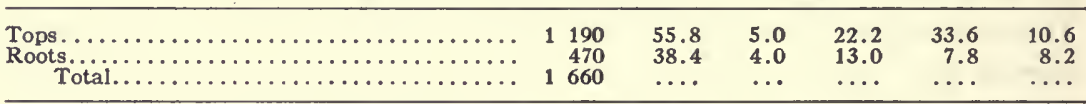

Southern Illinois, Cisne silt loam: soybeans, pod stage

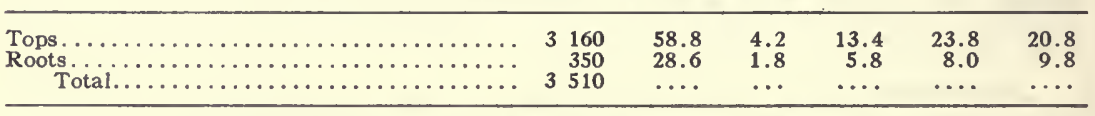

Northern Illinois, Elliot silt loam: soybeans, pod stage

\begin{tabular}{|c|c|c|c|c|c|c|}
\hline 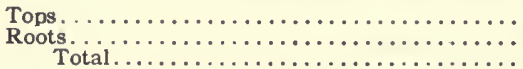 & $\begin{array}{r}4150 \\
510 \\
4660\end{array}$ & $\begin{array}{l}51.6 \\
23.6\end{array}$ & $\begin{array}{l}2.4 \\
2.4 \\
\cdots\end{array}$ & $\begin{array}{r}19.2 \\
7.4 \\
\cdots\end{array}$ & $\begin{array}{l}26.8 \\
11.1 \\
\cdots\end{array}$ & $\begin{array}{r}16.4 \\
9.4 \\
\end{array}$ \\
\hline
\end{tabular}

\section{NONLEGUME HAY AND FORAGE}

Grasses contained on the average about as much phosphorus per ton as did legumes but less nitrogen, calcium, magnesium, and iron. Nonlegumes contained more potassium and manganese than legumes (Table 1). 
Soil treatments increased the yields of grasses and also the percentages of various elements in the grasses. Seasons of continued rainfall and short drouth periods influenced the uptake of nitrogen, phosphorus, and potassium by the nonlegume crops. Most grasses flourished in mixed seedings with legumes and as a rule had an increased nitrogen and protein content because of such association.

\section{Kentucky Bluegrass}

What alfalfa is among legumes, Kentucky bluegrass is among nonlegumes. It is considered the most useful grass in the eastern and the central part of the corn belt. Among the many desirable characteristics is the high nutritive value of its protein and minerals.

Yield and composition of grass crops are readily influenced by soil treatment. Grasses grown with legumes have improved in yield and feeding quality.

On the Clayton experiment field, fertilizers increased both yield and quality of bluegrass hay. Ammonium sulfate increased the protein content 59 pounds per ton of hay; treble superphosphate added 2.5 pounds to the phosphorus content; and muriate of potash increased the potassium content by about 10 pounds per ton of hay (Table 17).

On the Urbana South Farm, limestone increased the protein content of bluegrass hay (Table 17). Here nitrogen fertilizers, in addition to other soil treatment (LPK), gave only small increases in the protein content of the hay, but the smallness of the increases was due largely to the relatively small amounts of nitrogen fertilizers applied (Table 17).

Also on the South Farm, rock phosphate (rP) and superphosphate (sP) substantially increased the phosphorus content of the bluegrass. Where the land was unphosphated, bluegrass hay was deficient in phosphorus, containing only 2.4 to 2.6 pounds per ton.

On the Trimpe farm various nitrogen fertilizers applied in rather large to excessive amounts increased the yield and the nitrogen content of bluegrass hay (Table 18). In these tests soybean meal produced the largest yield of bluegrass hay (4,710 pounds an acre) and the largest amounts of nitrogen (58.4 pounds) and phosphorus (5.0 pounds) per ton of hay. Phosphorus and potassium in soybean meal were apparently effective in increasing the amounts of these elements in the hay. Apparently the large application of soybean meal, a total of 15,680 pounds an acre over a period of four years, did not injure the bluegrass.

On the Trimpe farm, ammonium sulfate $\left(\left(\mathrm{NH}_{4}\right)_{2} \mathrm{SO}_{4}\right)$ when used 


\section{Table 17. - BLUEGRASS HAY: Yield and Chemical Composition Under Different Soil Treatments on Five Experiment Fields}

\begin{tabular}{|c|c|c|c|c|c|c|c|c|c|}
\hline \multirow{2}{*}{ Soil treatment* } & \multirow{2}{*}{$\begin{array}{l}\text { Hay } \\
\text { lb./A }\end{array}$} & $\mathbf{N}$ & Protein & $\mathbf{P}$ & $\mathrm{K}$ & $\mathrm{Ca}$ & $\mathbf{M g}$ & $\mathrm{Fe}$ & Mn \\
\hline & & \multicolumn{8}{|c|}{ Pounds per ton of hay } \\
\hline \multicolumn{10}{|c|}{ Clayton, May 25, 1939} \\
\hline 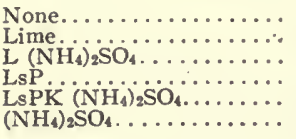 & $\begin{array}{ll} & 790 \\
& 840 \\
1 & 770 \\
910 \\
1 & 990 \\
1 & 640\end{array}$ & $\begin{array}{l}24.0 \\
26.0 \\
37.8 \\
24.2 \\
32.4 \\
34.0\end{array}$ & $\begin{array}{l}150 \\
162 \\
236 \\
151 \\
202 \\
212\end{array}$ & $\begin{array}{l}3.2 \\
3.6 \\
3.4 \\
5.4 \\
5.8 \\
3.2\end{array}$ & $\begin{array}{l}31.2 \\
32.4 \\
35.6 \\
30.6 \\
41.0 \\
36.4\end{array}$ & $\begin{array}{l}6.0 \\
6.8 \\
6.8 \\
6.8 \\
8.0 \\
5.2\end{array}$ & $\begin{array}{l}4.4 \\
3.4 \\
4.4 \\
4.4 \\
4.8 \\
4.8\end{array}$ & $\begin{array}{l}.20 \\
.28 \\
.38 \\
.34 \\
.06 \\
.38\end{array}$ & $\begin{array}{l}.59 \\
.08 \\
.25 \\
.11 \\
.20 \\
.46\end{array}$ \\
\hline 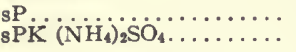 & $\begin{array}{r}960 \\
1790\end{array}$ & $\begin{array}{l}25.8 \\
33.6\end{array}$ & $\begin{array}{l}161 \\
210\end{array}$ & $\begin{array}{l}5.8 \\
6.2\end{array}$ & $\begin{array}{l}32.0 \\
46.2\end{array}$ & $\begin{array}{l}5.2 \\
5.2\end{array}$ & $\begin{array}{l}4.7 \\
4.8\end{array}$ & $\begin{array}{l}.10 \\
.58\end{array}$ & $\begin{array}{l}.38 \\
.40\end{array}$ \\
\hline
\end{tabular}

Elizabethtown, June 2, 1943

\begin{tabular}{|c|c|c|c|c|c|c|c|c|c|}
\hline $\begin{array}{l}\text { None. }{ }_{(\mathrm{NH}} \mathrm{SO}_{4} \mathrm{SO}_{4} \ldots \ldots \ldots \ldots \ldots \ldots \\
\text { Uramon } \ldots \ldots \ldots \ldots \ldots \\
\text { Soybean meal } \ldots \ldots \ldots \ldots \ldots\end{array}$ & $\begin{array}{ll} & 240 \\
2 & 100 \\
1 & 790 \\
1 & 910\end{array}$ & $\begin{array}{l}29.2 \\
60.0 \\
55.2 \\
55.6\end{array}$ & $\begin{array}{l}182 \\
375 \\
345 \\
348\end{array}$ & $\begin{array}{l}3.6 \\
3.2 \\
4.0 \\
4.0\end{array}$ & $\begin{array}{l}32.6 \\
54.2 \\
56.6 \\
48.8\end{array}$ & $\begin{array}{l}5.8 \\
2.4 \\
4.8 \\
3.6\end{array}$ & $\begin{array}{r}3.0 \\
1.0 \\
1.2 \\
.8\end{array}$ & $\begin{array}{l}.16 \\
.14 \\
.16 \\
.12\end{array}$ & $\begin{array}{l}.20 \\
.55 \\
.37 \\
.46\end{array}$ \\
\hline $\begin{array}{l}\mathrm{sP}\left(\mathrm{NH}_{4}\right)_{2} \mathrm{SO}_{4} \ldots \ldots \ldots \ldots \ldots \\
\mathrm{sP} \text { Uramon } \ldots \ldots \ldots \ldots \ldots \ldots \\
\mathrm{sP} \text { Soybean meal........ }\end{array}$ & $\begin{array}{ll}6 & 340 \\
4 & 740 \\
5 & 280\end{array}$ & $\begin{array}{l}60.4 \\
49.6 \\
50.4\end{array}$ & $\begin{array}{l}378 \\
310 \\
315\end{array}$ & $\begin{array}{l}6.6 \\
6.4 \\
6.6\end{array}$ & $\begin{array}{l}41.0 \\
37.8 \\
48.8\end{array}$ & $\begin{array}{l}5.0 \\
8.2 \\
6.4\end{array}$ & $\begin{array}{l}2.0 \\
3.8 \\
3.2\end{array}$ & $\begin{array}{r}.14 \\
.16 \\
.16\end{array}$ & $\begin{array}{r}.48 \\
.34 \\
.37\end{array}$ \\
\hline
\end{tabular}

Joliet, June 12, 1942

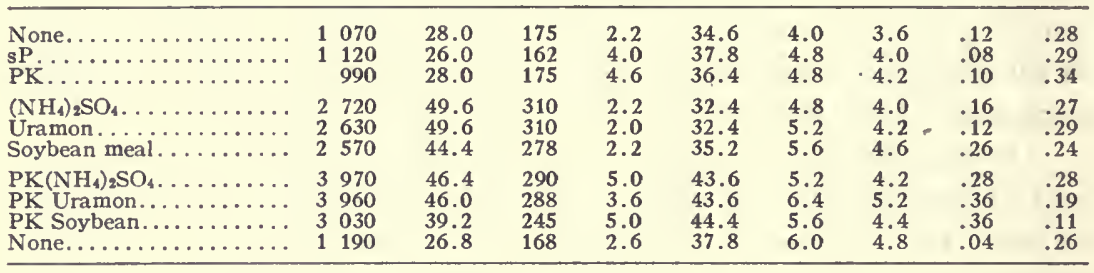

Lebanon, June 9, 1942

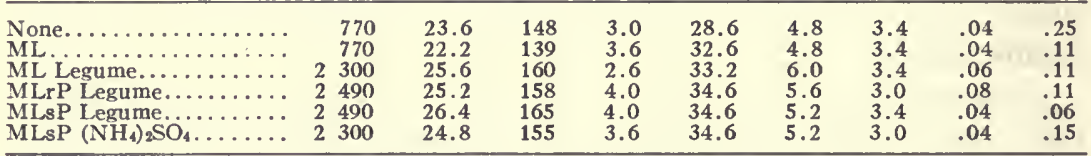

Urbana South Farm, June 6, 1941

\begin{tabular}{|c|c|c|c|c|c|c|c|c|c|}
\hline 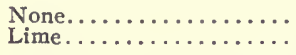 & $\begin{array}{r}970 \\
1200\end{array}$ & $\begin{array}{l}23.8 \\
26.0\end{array}$ & $\begin{array}{l}149 \\
162\end{array}$ & $\begin{array}{l}2.6 \\
2.4\end{array}$ & $\begin{array}{l}30.6 \\
32.6\end{array}$ & $\begin{array}{l}5.6 \\
5.2\end{array}$ & $\begin{array}{l}3.2 \\
4.0\end{array}$ & $\begin{array}{l}.36 \\
.36\end{array}$ & $\begin{array}{l}.44 \\
.34\end{array}$ \\
\hline${ }_{\mathrm{LrP}}^{\mathrm{rP}} \ldots \ldots \ldots \ldots \ldots \ldots \ldots \ldots$ & $\begin{array}{ll}1 & 010 \\
1 & 440\end{array}$ & $\begin{array}{l}23.4 \\
26.0\end{array}$ & $\begin{array}{l}146 \\
162\end{array}$ & $\begin{array}{l}3.8 \\
3.8\end{array}$ & $\begin{array}{l}31.2 \\
32.6\end{array}$ & $\begin{array}{l}6.8 \\
6.0\end{array}$ & $\begin{array}{l}3.8 \\
4.0\end{array}$ & .26 & $\begin{array}{l}.40 \\
.38\end{array}$ \\
\hline 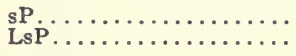 & $\begin{array}{ll}1 & 160 \\
1 & 390\end{array}$ & $\begin{array}{l}22.4 \\
27.2\end{array}$ & $\begin{array}{l}140 \\
170\end{array}$ & $\begin{array}{l}3.6 \\
3.8\end{array}$ & $\begin{array}{l}30.0 \\
30.6\end{array}$ & $\begin{array}{l}6.0 \\
6.4\end{array}$ & $\begin{array}{l}3.4 \\
3.8\end{array}$ & $\begin{array}{l}.28 \\
.28\end{array}$ & $\begin{array}{l}.46 \\
.38\end{array}$ \\
\hline $\begin{array}{l}\text { LsPK } \\
\text { LsPK } \underset{\mathrm{NaNO}}{\mathrm{Na}} \mathrm{N}_{3} \ldots \ldots \ldots \ldots \ldots \\
\text { LsPK }\left(\mathrm{NH}_{4}\right)_{2} \mathrm{SO}_{4} \ldots \ldots \ldots \ldots \\
\mathrm{LsPK} \mathrm{CaCN}_{2} \ldots \ldots \ldots \ldots \ldots\end{array}$ & $\begin{array}{ll}1 & 560 \\
3 & 200 \\
2 & 540 \\
2 & 400\end{array}$ & $\begin{array}{l}27.2 \\
29.6 \\
31.2 \\
27.6\end{array}$ & $\begin{array}{l}170 \\
185 \\
195 \\
172\end{array}$ & $\begin{array}{l}3.8 \\
3.2 \\
3.2 \\
3.2\end{array}$ & $\begin{array}{l}35.8 \\
33.8 \\
37.2 \\
36.4\end{array}$ & $\begin{array}{l}6.4 \\
6.0 \\
6.0 \\
6.8\end{array}$ & $\begin{array}{l}4.0 \\
3.8 \\
3.6 \\
3.4\end{array}$ & $\begin{array}{l}.24 \\
.08 \\
.12 \\
.10\end{array}$ & $\begin{array}{l}.35 \\
.26 \\
.26 \\
.28\end{array}$ \\
\hline
\end{tabular}

Aertilizers were applied yearly per acre as follows:

Clayton. ( $\left.\mathrm{NH}_{4}\right)_{2} \mathrm{SO}_{4}, 200$ pounds; sP $(0-45-0), 200$ pounds; $\mathrm{K}$ (muriate), 200 pounds.

Lebanon. Manure residual, $r \mathrm{P}$ and $\mathrm{sP}$ residual $\left(\mathrm{NH}_{4}\right)_{2} \mathrm{SO}_{4}, 200$ pounds.

Urbana. rP, 300 pounds; sP, 150 pounds; K (muriate), 100 pounds; $\mathrm{NaNO}_{3}, 133$ pounds; $\left(\mathrm{NH}_{4}\right)_{2} \mathrm{SO}_{4}, 100$ pounds; $\mathrm{CaCN}_{2}, 100$ pounds.

Elizabethtown. Total of three applications (March 1942, October 1942, March 1943): sP $(0-20-0), 750$ pounds; $\left(\mathrm{NH}_{4}\right)_{2} \mathrm{SO}_{4}, 1,500$ pounds; Uramon, 750 pounds; soybean meal, 4,800 pounds.

Joliet. Total of two applications (October 1941, April 1942): sP (0-20-0), 500 pounds; PK (0-20-20), 500 pounds; $\left(\mathrm{NH}_{4}\right)_{2} \mathrm{SO}_{4}, 1,000$ pounds; Uramon, 500 pounds; soybean meal, 3,200 pounds. 
in large amounts, 1,650 pounds an acre, considerably reduced the yield of bluegrass hay (Table 18). The nitrogen and protein content of this grass was, however, relatively high, but the content of phosphorus and potassium was relatively low where 1,650 pounds and 1,100 pounds of ammonium sulfate were used.

Activated sludge, flash dried, from the Sanitary District of Chicago, when used at the rather large rate of 18,820 pounds an acre, reduced the yield of bluegrass hay (Table 18). When used at lower rates, however, sludge increased the yield of hay and also its nitrogen content.

Powdered sulfur applied in relatively large amounts, 2,090 pounds and 3,140 pounds an acre, temporarily destroyed the stand of bluegrass. The small application, 1,040 pounds of sulfur per acre, increased the hay yield 770 pounds over the untreated check (Table 18).

On the alkaline ( $\mathrm{pH} \mathrm{8.1)} \mathrm{soils} \mathrm{of} \mathrm{the} \mathrm{Reich} \mathrm{farm,} \mathrm{sulfur} \mathrm{did} \mathrm{not}$ seriously harm bluegrass when applied in rather large amounts (Tables 18 and 19). During the late winter and early spring this land had a high water table, which apparently carried up sufficient lime material to overcome the acid reaction of the sulfur. In the course of four years these sulfur applications (2,350 pounds, 3,660 pounds, 7,320 pounds) affected the reaction of this soil but slightly.

On the Elizabethtown field superphosphate greatly increased both the yield and the phosphorus content of the bluegrass (Table 19). This soil is deficient in available phosphorus. During 1940, 1941, and 1942 the phosphorus content of bluegrass from untreated soil on this field averaged 1.8 pounds per ton of hay (Table 23). In June 1943, however, the phosphorus content of the hay from the untreated land was above 3 pounds per ton. This was due to the extremely rainy weather during May 1943; the rainfall evidently caused a higher availability of the soil phosphorus. A more nearly normal spring rainfall occurred in the years 1940, 1941, and 1942.

On the Joliet field ammonium sulfate and Uramon ${ }^{1}$ were about equally effective in increasing the yield and the protein content of bluegrass hay. Soybean meal was not so effective in this respect as the other two carriers. These fertilizers were used at rates which would supply the same amount of nitrogen from each. The phosphorus content of the bluegrass on this field was low except where phosphate fertilizers were used (Table 19).

'Trade name for urea that has been treated to improve its physical condition. 
Table 18. - BLUEGRASS HAY: Yield and Chemical Composition When Large, Medium, and Small Amounts of Various Materials Were Applied in Different Soil Treatments

\begin{tabular}{|c|c|c|c|c|c|c|c|c|c|}
\hline \multirow{2}{*}{$\begin{array}{c}\text { Treatment } \\
\text { Ib./A }\end{array}$} & \multirow{2}{*}{$\begin{array}{c}\text { Hay } \\
\text { lb./A }\end{array}$} & $\mathbf{N}$ & Protein & $\mathbf{P}$ & $\mathbf{K}$ & $\mathrm{Ca}$ & $\mathrm{Mg}$ & $\mathrm{Fe}$ & $\mathrm{Mn}$ \\
\hline & & \multicolumn{8}{|c|}{ Pounds per ton } \\
\hline \multicolumn{10}{|c|}{ Reich farm, June, 1941} \\
\hline \multicolumn{10}{|c|}{ Untreated } \\
\hline None... & 1350 & 25.6 & 160 & 3.4 & 34.0 & 4.0 & 2.6 & .10 & .06 \\
\hline \multicolumn{10}{|c|}{ Sulfur applied over 4 years } \\
\hline $\begin{array}{l}7320 \ldots \ldots \ldots \ldots \ldots \ldots \ldots \ldots \ldots \\
3 \\
3\end{array} 660 \ldots \ldots \ldots \ldots \ldots \ldots$ & $\begin{array}{ll}1 & 410 \\
1 & 260\end{array}$ & $\begin{array}{l}28.8 \\
28.8\end{array}$ & $\begin{array}{l}180 \\
180\end{array}$ & $\begin{array}{l}3.8 \\
4.0\end{array}$ & $\begin{array}{l}35.2 \\
35.2\end{array}$ & $\begin{array}{l}4.4 \\
4.8\end{array}$ & $\begin{array}{l}2.8 \\
2.4\end{array}$ & $\begin{array}{r}.18 \\
.20\end{array}$ & $\begin{array}{l}.04 \\
.06\end{array}$ \\
\hline $2350 \ldots \ldots \ldots \ldots \ldots \ldots \ldots$ & 1870 & 28.0 & 175 & 4.6 & 36.4 & 4.8 & 2.8 & .16 & .07 \\
\hline \multicolumn{10}{|c|}{$2-12-6$ applied over 2 years } \\
\hline 2350. & 2440 & 31.6 & 198 & 5.8 & 36.4 & 4.4 & 3.8 & .16 & .06 \\
\hline 1570. & 1950 & 32.4 & 202 & 5.4 & 35.8 & 5.2 & 3.0 & .18 & .09 \\
\hline 780. & 1590 & 30.0 & 188 & 4.6 & 32.0 & 4.8 & 3.0 & .12 & .10 \\
\hline \multicolumn{10}{|c|}{$\left(\mathrm{NH}_{4}\right)_{2} \mathrm{SO}_{4}$ applied over 4 years } \\
\hline 8620 & 2830 & 47.6 & 298 & 4.0 & 21.6 & 5.6 & 4.6 & .12 & .29 \\
\hline 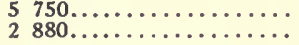 & $\begin{array}{ll}2 & 320 \\
2 & 280\end{array}$ & $\begin{array}{l}48.8 \\
35.2\end{array}$ & $\begin{array}{l}305 \\
220\end{array}$ & $\begin{array}{l}5.2 \\
5.0\end{array}$ & $\begin{array}{l}27.4 \\
30.6\end{array}$ & $\begin{array}{l}8.0 \\
7.2\end{array}$ & $\begin{array}{l}5.2 \\
4.2\end{array}$ & $\begin{array}{l}.18 \\
.10\end{array}$ & $\begin{array}{l}.34 \\
.19\end{array}$ \\
\hline \multicolumn{10}{|c|}{$\mathrm{MnSO}$, applied over 4 years } \\
\hline $1310 .$. & 1210 & 36.4 & 228 & 4.6 & 28.0 & 5.6 & 3.0 & .06 & .06 \\
\hline \multicolumn{10}{|c|}{ Trimpe farm, June, 1940} \\
\hline \multicolumn{10}{|c|}{ Untreated } \\
\hline None.. & 1260 & 26.0 & 162 & 3.8 & 29.4 & 4.8 & 3.2 & .14 & .09 \\
\hline \multicolumn{10}{|c|}{ Sulfur applied over 4 years } \\
\hline $\begin{array}{ll}3140 \ldots \\
2\end{array}$ & & $\cdots$ & $\cdots$ & $\cdots$ & $\cdots$ & $\cdots$ & $\ldots$ & ... & $\cdots$ \\
\hline 1040. & 2030 & 25.2 & $i \ddot{58}$ & $\ddot{3.6}$ & 39.8 & $\ddot{4} \ddot{8}$ & $\ddot{3.4}$ & $\because \ddot{1 i}$ & .34 \\
\hline \multicolumn{10}{|c|}{$\left(\mathrm{NH}_{4}\right)_{2} \mathrm{SO}_{4}$ applied over 4 years } \\
\hline 1650. & 3610 & 56.8 & 355 & 2.4 & 26.6 & 6.0 & 4.0 & .10 & .25 \\
\hline 1100 & 3940 & 51.6 & 322 & 2.8 & & & 5.2 & .10 & .24 \\
\hline 550 & 3820 & 42.0 & 262 & 2.8 & 35.9 & 6.0 & 4.0 & .10 & .27 \\
\hline \multicolumn{10}{|c|}{ Alfalfa meal applied over 4 years } \\
\hline (n., & 3400 & 32.8 & & 3.4 & 41.0 & 4.8 & 3.4 & .18 & .20 \\
\hline 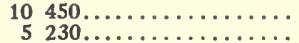 & $\begin{array}{l}2480 \\
2060\end{array}$ & 31.6 & 198 & $\begin{array}{l}3.2 \\
3.0\end{array}$ & 41.8 & 4 & 3. & .20 & .11 \\
\hline \multicolumn{10}{|c|}{ Soybean meal applied over 4 years } \\
\hline $15680 \ldots$ & 4710 & 58.4 & 365 & 5.0 & 41.8 & 8.4 & 5.0 & .30 & .13 \\
\hline 1045 & $\begin{array}{l}4270 \\
3\end{array}$ & 49.2 & 308 & 4.0 & 42.4 & 6. & 3.6 & .18 & .14 \\
\hline & 30 & 40 & & 3.6 & & 7.2 & 4.6 & .16 & .13 \\
\hline \multicolumn{10}{|c|}{ Sludge applied o } \\
\hline $18820 \ldots \ldots \ldots \ldots \ldots \ldots$ & 3430 & 41.6 & 260 & 3.2 & 33.8 & 8.0 & 5.0 & .20 & .10 \\
\hline $\begin{array}{rl}12 & 540 \\
6 & 270\end{array}$ & $\begin{array}{ll}3 & 800 \\
2 & 730\end{array}$ & 33.2 & $\begin{array}{l}208 \\
185\end{array}$ & 3.6 & 34.6 & 8.0 & $\begin{array}{l}4.6 \\
4.6\end{array}$ & .18 & .12 \\
\hline & & & & & & 9.0 & 4.0 & .12 & \\
\hline
\end{tabular}

Table 19. - COMPOSITION OF UNTREATED SOIL:" Reich and Trimpe Farms

\begin{tabular}{|c|c|c|c|c|}
\hline \multirow{2}{*}{ Farm } & $\mathrm{pH}$ & $\mathrm{N}$ & $\mathbf{P}$ & $\mathrm{K}$ \\
\hline & \multicolumn{4}{|c|}{ Pounds per acre } \\
\hline 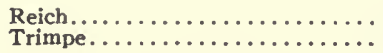 & $\begin{array}{l}8.1 \\
5.3\end{array}$ & $\begin{array}{ll}7 & 240 \\
4 & 800\end{array}$ & $\begin{array}{l}80 \\
50\end{array}$ & $\begin{array}{l}100 \\
170\end{array}$ \\
\hline
\end{tabular}

- Topsoil, about 7 inches. 
On the Lebanon field legumes consisting of clovers and lespedeza when grown in association with bluegrass increased the yield of the bluegrass and the protein content of the bluegrass hay. Both rock phosphate and superphosphate increased the phosphorus content of the bluegrass hay on this field.

\section{Timothy}

In certain sections of the United States timothy is a very popular hay grass. It is widely adaptable, is in general use, and is considered very palatable. Altho it is relatively low in protein and minerals, it responds to soil treatment both in yield and in increased protein and minerals. It grows well in mixtures with various legumes and its feeding quality is benefited by association with legumes.

Like other grasses in these tests, timothy contained higher percentages of protein and minerals at the earlier stages of growth. On the Unionville field the sampling in early May (Table 20) was considerably higher in nitrogen and minerals than was the sampling taken on July 10 from the same stand. On May 2, the timothy contained 31.2 pounds of nitrogen and 68.8 pounds of minerals per ton. On July 10, the nitrogen content was 19.8 pounds per ton and the mineral content 33.8 pounds per ton.

On the Newton field various nitrogen carriers considerably increased the yields of timothy hay and gave some increases (12 pounds per ton) in the protein content of the hay (Table 20). Where timothy was grown in association with legumes, mainly lespedeza, there was some increase in yields of, timothy and considerable increase (17 pounds per ton) in the protein content.

On the Lebanon field the timothy that was associated with legumes, clovers, and lespedeza showed an increase both in yield of hay and in protein content (Table 20). Ammonium sulfate produced a relatively large increase in the yield of timothy hay but caused no increase in protein content. It may be that the treatment was not heavy enough to increase the protein content.

On the South Farm at Urbana various legume associations with timothy and redtop increased the nitrogen and minerals in the nonlegume hay (Table 22). Some of the legumes appeared to be more effective than others. 
Table 20. - TIMOTHY HAY: Yield and Chemical Composition Under Different Soil Treatments on Four Fields

\begin{tabular}{|c|c|c|c|c|c|c|c|c|c|}
\hline \multirow{2}{*}{ Soil treatment } & \multirow{2}{*}{$\begin{array}{l}\text { Hay } \\
\text { Ib./A }\end{array}$} & $\mathbf{N}$ & Protein & $\mathbf{P}$ & $\mathbf{K}$ & $\mathrm{Ca}$ & $\mathbf{M g}$ & $\mathrm{Fe}$ & $\mathrm{Mn}$ \\
\hline & & \multicolumn{8}{|c|}{ Pounds per ton of hay } \\
\hline \multicolumn{10}{|c|}{ Lebanon, 3 years: 1940, 1941, 1942} \\
\hline 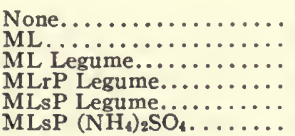 & $\begin{array}{ll}1 & 880 \\
2 & 270 \\
3 & 670 \\
3 & 280 \\
3 & 790 \\
4 & 460\end{array}$ & $\begin{array}{l}21.8 \\
21.4 \\
24.8 \\
23.0 \\
23.4 \\
20.4\end{array}$ & $\begin{array}{l}136 \\
134 \\
155 \\
144 \\
146 \\
128\end{array}$ & $\begin{array}{l}3.4 \\
3.6 \\
3.2 \\
3.8 \\
3.6 \\
3.2\end{array}$ & $\begin{array}{l}37.6 \\
34.8 \\
33.0 \\
35.6 \\
33.2 \\
30.6\end{array}$ & $\begin{array}{l}6.8 \\
7.4 \\
7.2 \\
8.2 \\
7.6 \\
8.0\end{array}$ & $\begin{array}{l}3.4 \\
3.2 \\
2.8 \\
3.0 \\
3.2 \\
3.6\end{array}$ & $\begin{array}{l}.24 \\
.14 \\
.18 \\
.12 \\
.10 \\
.18\end{array}$ & $\begin{array}{l}.24 \\
.14 \\
.12 \\
.18 \\
.21 \\
.14\end{array}$ \\
\hline
\end{tabular}

Newton, 3 years: 1939, 1940, 1941

\begin{tabular}{|c|c|c|c|c|c|c|c|c|c|}
\hline 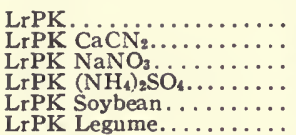 & $\begin{array}{ll}3 & 180 \\
4 & 060 \\
4 & 470 \\
4 & 410 \\
3 & 710 \\
3 & 640\end{array}$ & $\begin{array}{l}17.2 \\
18.2 \\
18.0 \\
19.2 \\
18.6 \\
20.0\end{array}$ & $\begin{array}{l}108 \\
114 \\
112 \\
120 \\
116 \\
125\end{array}$ & $\begin{array}{l}3.4 \\
2.8 \\
2.2 \\
2.6 \\
2.8 \\
2.6\end{array}$ & $\begin{array}{l}34.0 \\
31.0 \\
29.6 \\
27.2 \\
34.6 \\
33.6\end{array}$ & $\begin{array}{l}8.0 \\
8.7 \\
9.2 \\
8.6 \\
8.6 \\
7.8\end{array}$ & $\begin{array}{l}6.2 \\
4.0 \\
3.8 \\
3.6 \\
3.4 \\
3.8\end{array}$ & $\begin{array}{l}.36 \\
.18 \\
.08 \\
.16 \\
.08 \\
.16\end{array}$ & $\begin{array}{l}.16 \\
.13 \\
.10 \\
.29 \\
.17 \\
.17\end{array}$ \\
\hline
\end{tabular}

Unionville, 1932

\begin{tabular}{llllllll}
\hline \multicolumn{7}{c}{ May 2} \\
None.
\end{tabular}

Barry Brothers' farm, 1937

\begin{tabular}{|c|c|c|c|c|c|c|c|c|c|}
\hline $\begin{array}{l}\text { None. . . . . . . . . . . . . . . . . . . . } \\
\text { Lime. }\end{array}$ & $\begin{array}{ll}3 & 600 \\
3 & 400\end{array}$ & $\begin{array}{l}18.6 \\
18.8\end{array}$ & $\begin{array}{l}116 \\
118\end{array}$ & $\begin{array}{l}2.6 \\
3.0\end{array}$ & $\begin{array}{l}29.4 \\
34.6\end{array}$ & $\begin{array}{l}4.0 \\
3.6\end{array}$ & $\begin{array}{l}4.2 \\
4.0\end{array}$ & $\cdots$ & $\ldots$ \\
\hline $\begin{array}{l}\mathrm{sP} \ldots \ldots \ldots \ldots \ldots \ldots \\
\mathrm{rP} \ldots \ldots \ldots \ldots \ldots \ldots\end{array}$ & $\begin{array}{ll}3 & 820 \\
4 & 060\end{array}$ & $\begin{array}{l}18.4 \\
19.6\end{array}$ & $\begin{array}{l}115 \\
122\end{array}$ & $\begin{array}{l}3.0 \\
3.4\end{array}$ & $\begin{array}{l}40.0 \\
29.4\end{array}$ & $\begin{array}{l}4.4 \\
5.2\end{array}$ & $\begin{array}{l}3.8 \\
4.5\end{array}$ & $\cdots$ & $\begin{array}{l}\cdots \\
\cdots\end{array}$ \\
\hline $\begin{array}{l}\mathrm{LsPK}\left(\mathrm{NH}_{4}\right)_{2} \mathrm{SO}_{4} \ldots \ldots \ldots \ldots \\
\operatorname{LrPK}\left(\mathrm{NH}_{4}\right)_{2} \mathrm{SO}_{4} \ldots \ldots \ldots \ldots\end{array}$ & $\begin{array}{ll}6 & 920 \\
6 & 740\end{array}$ & $\begin{array}{l}20.4 \\
19.0\end{array}$ & $\begin{array}{l}128 \\
119\end{array}$ & $\begin{array}{l}2.6 \\
3.0\end{array}$ & $\begin{array}{l}33.2 \\
30.6\end{array}$ & $\begin{array}{l}4.6 \\
4.8\end{array}$ & $\begin{array}{l}4.0 \\
4.0\end{array}$ & $\cdots$ & $\ldots$ \\
\hline
\end{tabular}

- Fertilizers were applied yearly as follows per acre:

Lebanon. Manure residual, rP and $\mathrm{SP}$ residual $\left(\mathrm{NH}_{4}\right)_{2} \mathrm{SO}_{4}, 200$ pounds; legume, lespedeza and other clovers.

Newton. rP residual, $\mathrm{K}$ (muriate), 100 pounds; $\mathrm{CaCN}_{2}, 100$ pounds; $\mathrm{NaNO}_{3}, 133$ pounds;

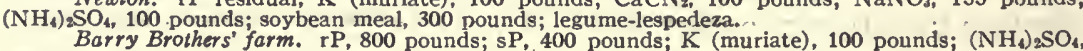
200 pounds. pounds.

Unionville. RLrPK residual, $\mathrm{CaCN}_{2}, 200$ pounds; $\left(\mathrm{NH}_{4}\right)_{2} \mathrm{SO}_{4}, 200$ pounds; $\mathrm{NaNO}_{3}, 266$

\section{Redtop}

Being adaptable to varying soils and climates, redtop grows well in many sections of the United States. In southern Illinois it is grown extensively for seed, hay, and pasture. It usually has more protein and minerals than timothy but is considered less palatable. 
Redtop responds well to various soil treatments. The benefits include rather large increases in yields of hay (2,050 pounds per acre for $\left(\mathrm{NH}_{4}\right)_{2} \mathrm{SO}_{4}$ on the Lebanon field) and in amounts of protein (14 pounds) per ton in the hay (Tables 21,22 , and 23).

Redtop is tolerant to manganese on the very acid soils of southern Illinois, as is shown by the amounts of this element in the hay (Table 23).

Table 21. - REDTOP HAY: Yield and Chemical Composition Under Different Soil Treatments on Two Fields

\begin{tabular}{|c|c|c|c|c|c|c|c|c|c|}
\hline \multirow{2}{*}{ Soil treatmenta } & \multirow{2}{*}{$\begin{array}{r}\text { Hay } \\
\text { lb./A }\end{array}$} & $\mathrm{N}$ & Protein & $\mathbf{P}$ & $\mathrm{K}$ & $\mathrm{Ca}$ & $\mathrm{Mg}$ & $\mathrm{Fe}$ & $\mathrm{Mn}$ \\
\hline & & \multicolumn{8}{|c|}{ Pounds per ton of hay } \\
\hline
\end{tabular}

Lebanon, 3 years: June 1940, 1941, 1942

\begin{tabular}{|c|c|c|c|c|c|c|c|c|c|}
\hline 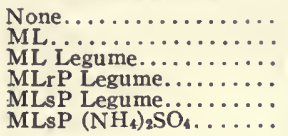 & $\begin{array}{ll}2 & 230 \\
2 & 100 \\
3 & 360 \\
3 & 370 \\
3 & 290 \\
4 & 280\end{array}$ & $\begin{array}{l}21.2 \\
21.6 \\
23.6 \\
23.0 \\
24.4 \\
23.4\end{array}$ & $\begin{array}{l}132 \\
135 \\
148 \\
144 \\
152 \\
146\end{array}$ & $\begin{array}{l}3.2 \\
3.4 \\
3.0 \\
3.8 \\
3.8 \\
3.2\end{array}$ & $\begin{array}{l}32.6 \\
36.2 \\
36.0 \\
35.0 \\
34.0 \\
32.4\end{array}$ & $\begin{array}{r}8.4 \\
8.4 \\
9.4 \\
8.0 \\
9.6 \\
10.2\end{array}$ & $\begin{array}{l}5.0 \\
4.0 \\
4.4 \\
3.4 \\
4.8 \\
5.0\end{array}$ & $\begin{array}{l}.14 \\
.20 \\
.14 \\
.14 \\
.10 \\
.18\end{array}$ & $\begin{array}{l}.80 \\
.30 \\
.31 \\
.23 \\
.17 \\
.35\end{array}$ \\
\hline
\end{tabular}

Newton, 3 years: June 1939, 1940, 1941

\begin{tabular}{|c|c|c|c|c|c|c|c|c|c|}
\hline $\begin{array}{l}\mathrm{LrPK} \\
\mathrm{LrPK} \\
\mathrm{LrPK} \\
\mathrm{LrPCN} \\
\mathrm{LrPK} \\
\mathrm{Lr} \mathrm{NaO}_{3} \ldots \ldots \ldots \ldots\end{array}$ & $\begin{array}{ll}2 & 970 \\
3 & 620 \\
4 & 330 \\
4 & 030 \\
3 & 370 \\
3 & 980\end{array}$ & $\begin{array}{l}19.2 \\
19.6 \\
19.6 \\
19.8 \\
20.4 \\
21.6\end{array}$ & $\begin{array}{l}120 \\
122 \\
122 \\
124 \\
128 \\
135\end{array}$ & $\begin{array}{l}3.4 \\
3.8 \\
3.4 \\
3.6 \\
3.4 \\
3.6\end{array}$ & $\begin{array}{l}34.0 \\
33.0 \\
30.8 \\
30.6 \\
33.4 \\
33.6\end{array}$ & $\begin{array}{l}10.0 \\
10.4 \\
10.6 \\
10.4 \\
10.6 \\
10.4\end{array}$ & $\begin{array}{l}6.0 \\
5.6 \\
6.6 \\
6.4 \\
6.0 \\
5.8\end{array}$ & $\begin{array}{l}.12 \\
.12 \\
.17 \\
.18 \\
.16 \\
.20\end{array}$ & $\begin{array}{l}.34 \\
.34 \\
.33 \\
.58 \\
.46 \\
.37\end{array}$ \\
\hline
\end{tabular}

- Fertilizer applications were the same as those shown for Lebanon and Newton in Table 20.

Table 22. - TIMOTHY AND REDTOP HAYS: Chemical Composition When Grown With Different Legumes

(Urbana South Farm, June 24, 1932)

\begin{tabular}{|c|c|c|c|c|c|c|c|}
\hline \multirow{2}{*}{ Grass } & \multirow{2}{*}{ Legume association } & $\mathrm{N}$ & Protein & $\mathbf{P}$ & $\mathbf{K}$ & $\mathrm{Ca}$ & $\mathbf{M g}$ \\
\hline & & \multicolumn{6}{|c|}{ Pounds per ton of hay } \\
\hline 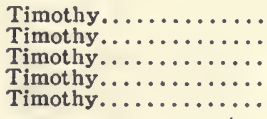 & 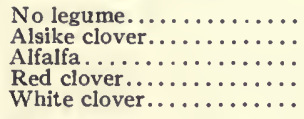 & $\begin{array}{l}18.9 \\
27.9 \\
23.9 \\
20.6 \\
23.9\end{array}$ & $\begin{array}{l}118 \\
174 \\
150 \\
130 \\
150\end{array}$ & $\begin{array}{l}2.8 \\
3.5 \\
3.4 \\
3.2 \\
3.0\end{array}$ & $\begin{array}{l}24.7 \\
31.2 \\
28.6 \\
28.0 \\
27.2\end{array}$ & $\begin{array}{l}4.0 \\
5.1 \\
4.9 \\
4.1 \\
4.4\end{array}$ & $\begin{array}{l}3.1 \\
3.4 \\
3.9 \\
3.3 \\
3.6\end{array}$ \\
\hline 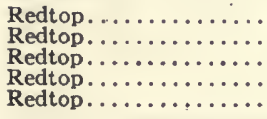 & 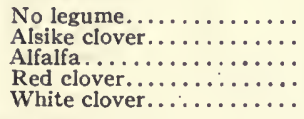 & $\begin{array}{l}25.9 \\
29.8 \\
30.1 \\
28.1 \\
29.2\end{array}$ & $\begin{array}{l}162 \\
186 \\
188 \\
176 \\
182\end{array}$ & $\begin{array}{l}3.4 \\
4.0 \\
3.8 \\
3.9 \\
3.6\end{array}$ & $\begin{array}{l}28.6 \\
30.6 \\
33.2 \\
26.2 \\
31.2\end{array}$ & $\begin{array}{l}7.2 \\
7.5 \\
8.5 \\
8.3 \\
7.2\end{array}$ & $\begin{array}{l}4.9 \\
4.9 \\
5.7 \\
5.1 \\
4.9\end{array}$ \\
\hline
\end{tabular}

\section{Orchard Grass}

Orchard grass is a bunch type of pasture grass, which grows well under different climatic conditions. It is well adapted to pasture and is used successfully for this purpose in some sections. In these tests 
orchard grass compared favorably with redtop and timothy in yield of hay, but the hay was usually coarse and stemmy.

Soil treatment increased the feeding quality of orchard grass and also the yields. Applications of a nitrogen fertilizer and association with a legume increased both the yield of hay and its protein content. Phosphate fertilizers were effective in increasing the phosphorus content of the hay (Tables 23 and 24). On the Elizabethtown field the orchard grass on the untreated land contained 2.0 pounds of phosphorus per ton of hay. The use of $0-20-0$ increased the phosphorus content to 4.2 pounds per ton.

The manganese content of orchard grass averaged higher than the manganese content of the other nonlegumes.

\section{Table 23. - BLUEGRASS, TIMOTHY, REDTOP, ORCHARD GRASS: Chemical Composition When Grown on a Phosphorus-Deficient Soil Treated With Different Phosphate Fertilizers}

(Elizabethtown field, 3 years: 1940, 1941, 1942)

\begin{tabular}{|c|c|c|c|c|c|c|c|c|}
\hline \multirow{2}{*}{ Soil treatment } & $\mathrm{N}$ & Protein & $\mathbf{P}$ & $\mathrm{K}$ & $\mathrm{Ca}$ & $\mathrm{Mg}$ & $\mathrm{Fe}$ & $\mathrm{Mn}$ \\
\hline & \multicolumn{8}{|c|}{ Pounds per ton of hay } \\
\hline \multicolumn{9}{|c|}{ Kentucky bluegrass } \\
\hline 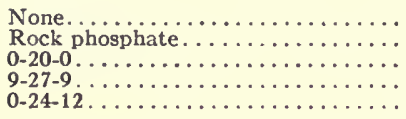 & $\begin{array}{l}23.6 \\
21.4 \\
22.0 \\
21.4 \\
20.6\end{array}$ & $\begin{array}{l}148 \\
134 \\
138 \\
134 \\
129\end{array}$ & $\begin{array}{l}1.8 \\
3.4 \\
4.2 \\
3.2 \\
3.6\end{array}$ & $\begin{array}{l}26.8 \\
27.8 \\
30.4 \\
29.8 \\
30.1\end{array}$ & $\begin{array}{l}6.6 \\
7.4 \\
7.2 \\
5.6 \\
6.2\end{array}$ & $\begin{array}{l}4.0 \\
3.6 \\
3.4 \\
2.8 \\
3.4\end{array}$ & $\begin{array}{l}.18 \\
.14 \\
.12 \\
.22 \\
.30\end{array}$ & $\begin{array}{l}.20 \\
.19 \\
.29 \\
.14 \\
.22\end{array}$ \\
\hline \multicolumn{9}{|c|}{ Timothy } \\
\hline 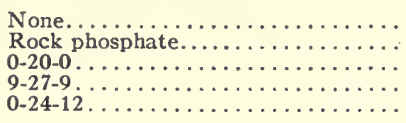 & $\begin{array}{l}21.6 \\
19.0 \\
18.6 \\
21.2 \\
18.2\end{array}$ & $\begin{array}{l}135 \\
119 \\
116 \\
132 \\
114\end{array}$ & $\begin{array}{l}1.6 \\
2.6 \\
2.8 \\
2.4 \\
2.8\end{array}$ & $\begin{array}{l}32.6 \\
34.6 \\
33.4 \\
32.6 \\
35.2\end{array}$ & $\begin{array}{l}5.8 \\
5.0 \\
5.0 \\
6.4 \\
5.4\end{array}$ & $\begin{array}{l}3.2 \\
3.2 \\
3.0 \\
3.4 \\
3.2\end{array}$ & $\begin{array}{l}.18 \\
.12 \\
.14 \\
.16 \\
.16\end{array}$ & $\begin{array}{l}.17 \\
.20 \\
.22 \\
.20 \\
.24\end{array}$ \\
\hline \multicolumn{9}{|c|}{ Redtop } \\
\hline 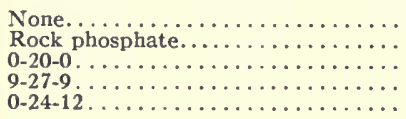 & $\begin{array}{l}23.6 \\
20.0 \\
21.6 \\
21.2 \\
19.9\end{array}$ & $\begin{array}{l}148 \\
125 \\
135 \\
132 \\
124\end{array}$ & $\begin{array}{l}2.0 \\
2.8 \\
3.6 \\
2.8 \\
4.0\end{array}$ & $\begin{array}{l}33.4 \\
32.4 \\
33.2 \\
36.0 \\
33.6\end{array}$ & $\begin{array}{l}7.4 \\
6.8 \\
6.8 \\
7.2 \\
7.0\end{array}$ & $\begin{array}{l}3.6 \\
3.6 \\
4.4 \\
3.6 \\
4.0\end{array}$ & $\begin{array}{l}.18 \\
.18 \\
.10 \\
.16 \\
.24\end{array}$ & $\begin{array}{l}.38 \\
.43 \\
.88 \\
.48 \\
.91\end{array}$ \\
\hline
\end{tabular}

Orchard grass

\begin{tabular}{|c|c|c|c|c|c|c|c|c|}
\hline 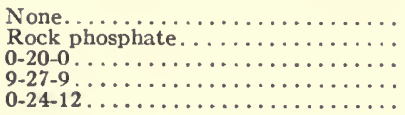 & $\begin{array}{l}18.4 \\
19.4 \\
17.8 \\
16.6 \\
15.4\end{array}$ & $\begin{array}{r}115 \\
121 \\
111 \\
104 \\
96\end{array}$ & $\begin{array}{l}2.0 \\
3.8 \\
4.2 \\
3.0 \\
3.8\end{array}$ & $\begin{array}{l}37.4 \\
35.8 \\
35.2 \\
35.0 \\
37.4\end{array}$ & $\begin{array}{l}5.1 \\
6.0 \\
5.2 \\
5.0 \\
6.0\end{array}$ & $\begin{array}{l}4.6 \\
4.0 \\
4.0 \\
4.0 \\
3.8\end{array}$ & $\begin{array}{l}.22 \\
.08 \\
.26 \\
.14 \\
.12\end{array}$ & $\begin{array}{l}.52 \\
.74 \\
.60 \\
.63 \\
.58\end{array}$ \\
\hline
\end{tabular}

"Total fertilizers added during 11-year period were: rock phosphate, 2,750 pounds an acre; $0-20-0,2,200$ pounds; $9-27-9,825$ pounds; $0-24-12,2,750$ pounds. 
Table 24. - ORCHARD GRASS: Yield and Chemical Composition Under Different Soil Treatments

(Lebanon, June 9, 1942)

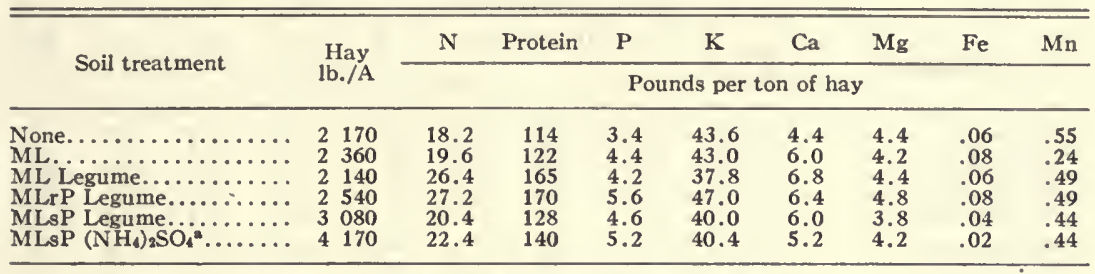

- Fertilizer applications were the same as those shown in Table 20.

\section{Bromegrass}

Bromegrass has a wide range of adaptability. It is resistant to extremes of drouth and temperature, a quality that adds to its desirability as a pasture grass. When properly managed, it is long-lived and productive of pasture and hay, and in some regions it is harvested for seed.

As bromegrass needs a good supply of available nitrogen for its best growth, nitrogen fertilizers increased its protein content as well as its yields. The same response was obtained by growing bromegrass in association with legumes. Alfalfa has proved an unusually good source of nitrogen for bromegrass when the two are grown together (Table 25). When bromegrass was grown with alfalfa on the Newton field, the increase in protein in the bromegrass was 90 pounds per ton of hay.

\section{Bluestem}

Big bluestem, or prairie grass, is a native plant which is said to have grown luxuriantly on a large part of our prairies before they were put to the plow. The samples analyzed in this study were collected in fencerows, roadways, and other uncultivated places. In amounts of nitrogen, protein, and minerals, bluestem is similar to timothy and redtop (Tables 1 and 26).

\section{Cornstalks}

Cornstalks are relatively low in protein and extremely low in phosphorus. They contain other minerals in amounts comparable to those of other nonlegume forage crops and hay crops (Tables 1 and 27). The cornstalks used in these analyses included main stalk, leaves, sheath, and husk (Table 28). The samples were collected when the husk was 
Table 25. - BROMEGRASS HAY: Yield and Chemical Composition Under Different Soil Treatments and Different Legume Associations

(Newton field, 2 years: June 1942 and 1943)

\begin{tabular}{|c|c|c|c|c|c|c|c|c|c|}
\hline \multirow{2}{*}{ Soil treatment } & \multirow{2}{*}{$\begin{array}{r}\text { Hay } \\
\text { lb./A }\end{array}$} & $\mathbf{N}$ & Protein & $\mathbf{P}$ & $\mathbf{K}$ & $\mathrm{Ca}$ & $\mathrm{Mg}$ & $\mathrm{Fe}$ & Mn \\
\hline & & \multicolumn{8}{|c|}{ Pounds per ton of hay } \\
\hline 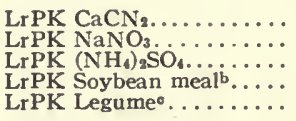 & $\begin{array}{ll}1 & 980 \\
2 & 760 \\
2 & 770 \\
1 & 970 \\
1 & 970\end{array}$ & $\begin{array}{l}25.7 \\
25.0 \\
25.9 \\
24.1 \\
28.2\end{array}$ & $\begin{array}{l}161 \\
156 \\
162 \\
150 \\
176\end{array}$ & $\begin{array}{l}3.0 \\
3.0 \\
3.1 \\
3.7 \\
4.1\end{array}$ & $\begin{array}{l}42.0 \\
34.2 \\
35.2 \\
35.2 \\
42.1\end{array}$ & $\begin{array}{l}8.4 \\
7.3 \\
7.9 \\
6.8 \\
8.6\end{array}$ & $\begin{array}{l}2.9 \\
1.5 \\
2.7 \\
2.7 \\
2.3\end{array}$ & $\begin{array}{l}.08 \\
.12 \\
.10 \\
.17 \\
.14\end{array}$ & $\begin{array}{l}.24 \\
.32 \\
.18 \\
.26 \\
.21\end{array}$ \\
\hline $\begin{array}{l}\text { rPK no alfalfad } \ldots \ldots \ldots \ldots \\
\text { LrPK Alfalfa } \ldots \ldots \ldots \ldots\end{array}$ & $\begin{array}{ll}1 & 560 \\
2 & 030^{f}\end{array}$ & $\begin{array}{l}27.0 \\
41.4\end{array}$ & $\begin{array}{l}168 \\
258\end{array}$ & $\begin{array}{l}3.4 \\
3.8\end{array}$ & $\begin{array}{l}46.5 \\
42.6\end{array}$ & $\begin{array}{l}6.9 \\
7.8\end{array}$ & $\begin{array}{l}2.3 \\
4.0\end{array}$ & $\begin{array}{l}.14 \\
.12\end{array}$ & $\begin{array}{l}.30 \\
.13\end{array}$ \\
\hline
\end{tabular}

- Fertilizer applications were the same as those shown for Newton in Table 20.

b Soybean meal applied to soil.

- Legume-lespedeza association.

d 1943 only.

- Alfalfa association.

1 Alfalfa and bromegrass.

\section{Table 26. - BIG BLUESTEM GRASS: Chemical Composition at Different Growth Stages on Three Fields}

\begin{tabular}{|c|c|c|c|c|c|c|c|c|}
\hline \multirow{2}{*}{ Stage of growth } & $\mathrm{N}$ & Protein & $\mathbf{P}$ & K & $\mathrm{Ca}$ & $\mathrm{Mg}$ & $\mathrm{Fe}$ & $\mathrm{Mn}$ \\
\hline & \multicolumn{8}{|c|}{ Pounds per ton of hay } \\
\hline \multicolumn{9}{|c|}{ Newton, July 1941} \\
\hline 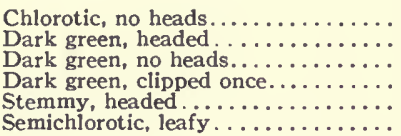 & $\begin{array}{l}21.2 \\
18.0 \\
22.0 \\
23.6 \\
22.4 \\
22.6\end{array}$ & $\begin{array}{l}132 \\
112 \\
138 \\
148 \\
140 \\
141\end{array}$ & $\begin{array}{l}4.0 \\
3.0 \\
2.6 \\
3.4 \\
2.6 \\
4.4\end{array}$ & $\begin{array}{l}31.2 \\
28.6 \\
33.8 \\
37.8 \\
34.6 \\
28.6\end{array}$ & $\begin{array}{l}9.2 \\
8.4 \\
8.4 \\
7.6 \\
8.0 \\
6.8\end{array}$ & $\begin{array}{l}4.8 \\
4.6 \\
3.2 \\
3.2 \\
3.2 \\
4.6\end{array}$ & $\begin{array}{l}.22 \\
.16 \\
.12 \\
.18 \\
.42 \\
.44\end{array}$ & $\begin{array}{l}.20 \\
.11 \\
.13 \\
.15 \\
.06 \\
.14\end{array}$ \\
\hline
\end{tabular}

Northern Illinois, October-November, 1938

\begin{tabular}{|c|c|c|c|c|c|c|c|c|}
\hline $\begin{array}{l}\text { Seed stage. } \ldots \ldots \ldots \ldots \ldots \ldots \ldots \ldots \ldots \\
\text { Seed stage. } \ldots \ldots \ldots \ldots \ldots \ldots \ldots \ldots\end{array}$ & $\begin{array}{l}21.0 \\
14.8\end{array}$ & $\begin{array}{r}131 \\
92\end{array}$ & $\begin{array}{l}3.4 \\
2.6\end{array}$ & $\begin{array}{l}23.0 \\
16.2\end{array}$ & $\begin{array}{l}8.4 \\
5.6\end{array}$ & $\begin{array}{l}4.6 \\
4.6\end{array}$ & $\begin{array}{l}.80 \\
.20\end{array}$ & $\begin{array}{l}.08 \\
.04\end{array}$ \\
\hline
\end{tabular}

Dixon Springs, June 1944

\begin{tabular}{llllllllll}
\hline Leafy, no heads (untreated) $\ldots \ldots \ldots$ & 24.0 & 150 & 2.4 & 33.2 & 6.0 & 3.2 & .10 & .14 \\
Leafy, no heads (limed) $\ldots \ldots \ldots \ldots \ldots$ & 20.8 & 168 & 2.6 & 30.0 & 7.2 & 3.9 & .10 & .06 \\
\hline
\end{tabular}

dry and the grain fully dented. They probably contained more minerals and proteins than they would have contained if the stalks had stood in the fields several weeks after the ear had become mature.

The chemical composition of cornstalks may be changed considerably by soil treatments, as is shown by Table 27 . Phosphorus treatment usually increased the phosphorus content of the stalks, but in only one instance was the total amount of phosphorus in the stalks of a treated plot above 3 pounds a ton. It is also evident from the experiment on 
Table 27.-CORNSTALKS: Chemical Composition When Grown Under Different Soil Treatments

(Stalks, blades, sheath, and husk are included)

\begin{tabular}{llllllllll}
\hline \hline \multirow{2}{*}{ Soil treatment } & N & Protein & P & K & $\mathrm{Ca}$ & $\mathrm{Mg}$ & $\mathrm{Fe}$ & $\mathrm{Mn}$ \\
\cline { 2 - 6 } & \multicolumn{8}{c}{ Pounds per ton of stalks }
\end{tabular}

Garvis farm, September 10, 1942

\begin{tabular}{l} 
None. $\ldots \ldots \ldots \ldots \ldots \ldots \ldots \ldots \ldots$ \\
NaNO \\
\hline
\end{tabular}

Stroh farm, September 10, 1942

\begin{tabular}{|c|c|c|c|c|c|c|c|c|}
\hline 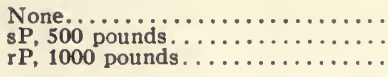 & $\begin{array}{l}17.8 \\
18.6 \\
18.8\end{array}$ & $\begin{array}{l}111 \\
116 \\
118\end{array}$ & $\begin{array}{l}1.2 \\
1.0 \\
1.0\end{array}$ & $\begin{array}{l}39.2 \\
39.2 \\
36.4\end{array}$ & $\begin{array}{r}9.6 \\
12.8 \\
14.0\end{array}$ & $\begin{array}{l}9.2 \\
8.2 \\
7.0\end{array}$ & $\begin{array}{l}.30 \\
.62 \\
.56\end{array}$ & $\begin{array}{l}.12 \\
.15 \\
.15\end{array}$ \\
\hline
\end{tabular}

Young farm, September 16, 1942

\begin{tabular}{|c|c|c|c|c|c|c|c|c|}
\hline None. $i 1 / \ldots \ldots \ldots \ldots \ldots \ldots \ldots$ & 25.0 & 156 & 1.8 & 29.6 & 9.6 & 8.0 & .22 & .29 \\
\hline 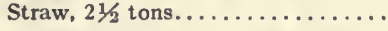 & 15.8 & 99 & 1.4 & 28.2 & 10.0 & 8.0 & .96 & .20 \\
\hline
\end{tabular}

Kewanee field, September 29, 1943

\begin{tabular}{|c|c|c|c|c|c|c|c|c|}
\hline \multicolumn{9}{|c|}{ Hybrid U.S. 5} \\
\hline $\begin{array}{l}\text { None } \ldots \ldots \ldots \ldots \ldots \ldots \ldots \ldots \ldots \ldots \\
\text { RLrP } \\
\text { RLrPK. }\end{array}$ & $\begin{array}{l}15.8 \\
15.0 \\
14.2\end{array}$ & $\begin{array}{l}99 \\
94 \\
89\end{array}$ & $\begin{array}{l}1.4 \\
2.4 \\
3.8\end{array}$ & $\begin{array}{l}22.8 \\
29.4 \\
43.0\end{array}$ & $\begin{array}{r}10.8 \\
10.0 \\
9.6\end{array}$ & $\begin{array}{l}8.8 \\
4.8 \\
5.6\end{array}$ & $\begin{array}{l}.94 \\
.62 \\
.48\end{array}$ & $\begin{array}{l}.27 \\
.06 \\
.05\end{array}$ \\
\hline \multicolumn{9}{|c|}{ Hybrid Illinois 201} \\
\hline 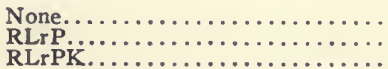 & $\begin{array}{l}13.8 \\
16.0 \\
18.2\end{array}$ & $\begin{array}{r}86 \\
100 \\
114\end{array}$ & $\begin{array}{l}1.2 \\
1.8 \\
2.6\end{array}$ & $\begin{array}{l}20.8 \\
28.0 \\
41.8\end{array}$ & $\begin{array}{l}10.8 \\
10.0 \\
10.0\end{array}$ & $\begin{array}{l}7.2 \\
6.0 \\
5.4\end{array}$ & $\begin{array}{l}.56 \\
.64 \\
.64\end{array}$ & $\begin{array}{l}.14 \\
.10 \\
.10\end{array}$ \\
\hline
\end{tabular}

Sparta field, September 4, 1942

\begin{tabular}{|c|c|c|c|c|c|c|c|c|}
\hline 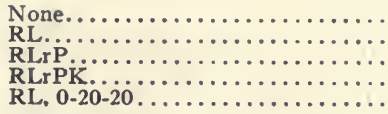 & $\begin{array}{l}12.4 \\
14.8 \\
14.4 \\
17.0 \\
14.6\end{array}$ & $\begin{array}{r}77 \\
92 \\
90 \\
106 \\
91\end{array}$ & $\begin{array}{l}1.0 \\
1.6 \\
2.4 \\
2.2 \\
2.4\end{array}$ & $\begin{array}{l}24.8 \\
14.8 \\
20.2 \\
40.0 \\
33.2\end{array}$ & $\begin{array}{r}8.0 \\
12.8 \\
14.4 \\
10.0 \\
10.4\end{array}$ & $\begin{array}{l}4.4 \\
8.4 \\
8.6 \\
4.4 \\
4.8\end{array}$ & $\begin{array}{l}.14 \\
.10 \\
.06 \\
.06 \\
.08\end{array}$ & $\begin{array}{l}1.76 \\
.18 \\
.17 \\
.16 \\
.18\end{array}$ \\
\hline
\end{tabular}

the Kewanee field that hybrids differ in their ability to utilize soil treatment and increase the mineral and the protein content of the stalks.

As livestock eat mainly the blade, sheath, and husk, and not the main stalk to any great extent, it is important to know the feeding value of the various parts of the stover. The main stalk makes up about 41 percent of the entire plant; the blades, about 25 percent, and the sheath and husk, the other 34 percent. The ear was not included in these percentage calculations. Blades contained the highest feeding value as judged by protein and minerals. The sheath and the husk were but slightly higher in protein content than was the main stalk. The blades had the most iron and manganese; the grain and cob had relatively little of these two elements. 
Table 28. - CORN PLANT: Chemical Composition of Various Parts of the Mature Plant

(Samples taken from Kewanee, Newton, Enfield, and Elizabethtown fields and the Morrow plots, Urbana)

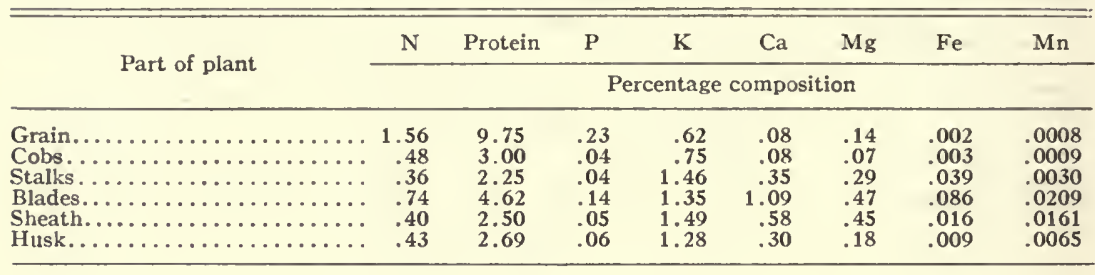

\section{SUMMARY}

This study confirms the findings of many other investigators that not only do various legumes and grasses vary rather widely in their chemical content, but also that plants of the same species show considerable variation in their chemical content. In this study variation in composition was found to be caused by natural differences in soils, soil treatment, periods of rainfall, short drouth periods, and legume associations. Soil treatments, however, probably caused the greatest range in composition in a single species.

As judged by total protein content and by mineral content, alfalfa had the highest feeding value of any of the important hay crops grown under Illinois conditions. The protein content of alfalfa hay was equally high on soils of different productivity levels.

The percentages of phosphorus and potassium in both the legumes and the nonlegumes varied with the amounts of these elements available in the soils. When phosphorus and potassium were applied to the land, there was as a rule an increase of each element in the hay. The calcium and magnesium content of legume hays was relatively high, and the amounts of these two elements were rather closely related to the potassium content of the hay.

A number of soils in Illinois produce legume and nonlegume hay and forage that contain less than 3 pounds of phosphorus per ton of dry weight. Three pounds is considered the least amount that will make these hays nutritionally safe for livestock feeding.

Different cuttings of alfalfa during a single season varied only slightly in nitrogen and protein content. There was no evidence of any considerable translocation of nitrogen, phosphorus, or potassium from tops to roots in the last cutting of alfalfa hay harvested in September and October. 
Red-clover hay averaged slightly lower than alfalfa in nitrogen, protein, and minerals. Various soil treatments increased the yields of red-clover hay and on some soils increased the amount of protein in the hay. When phosphorus was included in the treatment, the hay generally had a higher phosphorus content.

Korean lespedeza averaged considerably lower than alfalfa in nitrogen and minerals; and was somewhat lower in these constituents than were most of the other legumes. It was especially low in calcium and magnesium.

Lespedeza responded to various soil treatments with larger yields of hay and with higher percentages of phosphorus and potassium when these elements were included in the soil treatment.

Sweet clover grown on dark soils and used as a plow-under crop can add a very large amount of nitrogen, and it can do this without occupying the land exclusively thru an entire season.

On the light-colored soils of southern Illinois the sweet-clover crop apparently did not fix enough nitrogen to maintain a supply similar to that maintained on the dark soils of central and northern Illinois.

Removing a fall hay crop of sweet clover the same year the clover was seeded had an effect similar to heavy pasturing and reduced the growth of roots and tops the following spring.

Soybeans as a plow-under crop equaled alfalfa in weight of roots and tops an acre at the pod stage. Alfalfa at the hay stage was superior to soybeans in pounds of nitrogen an acre. Of the four crops compared - alfalfa, sweet clover, lespedeza, and soybeans - sweet clover in the spring yielded the least dry matter to the acre. On the dark soils sweet clover was far superior to the other crops in amounts of nitrogen, phosphorus, and potassium per ton of roots and tops.

Among the nonlegumes Kentucky bluegrass and bromegrass had the highest feeding values as judged by protein and mineral content. Both grasses responded to various soil treatments with larger yields of dry matter and usually with a higher content of nitrogen, phosphorus, and potassium, depending on the nature of the treatment.

Redtop was slightly higher in protein than either timothy or orchard grass, altho there was not a great difference in the average composition of the three grasses at hay stage. All three grasses responded to soil treatment by producing larger yields and yields with higher percentages of the elements considered in this study.

Bromegrass appeared to give larger response in nitrogen content when grown in association with legumes. All the grasses, however, responded to legume association. 
Cornstalks - including the main stalk, blades, sheath, and husk had very' low percentages of protein and phosphorus. They had a slightly higher content of calcium and magnesium than had the other nonlegumes. The chemical composition was increased by various soil treatments, but even under the best treatment the feeding quality of cornstalks was low.

\section{LITERATURE CITED}

1. Archibald, J. G., and Bennett, E. Chemical composition of herbage for Massachusetts pastures. Mass. Agr. Exp. Sta. Bul. 30. 1933.

2. Fraps, C. S., and Fudge, J. F. Phosphoric acid, lime and protein in forage grasses of the east Texas timber country. Soil Sci. Soc. Amer. Proc. 2, 347-351. 1937.

3. Hamilton, Tom S. Phosphorus in human and animal health. Paper given at the Western Phosphate Conference, Sept. 1940.

4. Jacob, Duncan, Williams, Morrell, Bible, McFarlin, and Snyder. Highphosphorus vs. low-phosphorus red-clover hay for growing calves. Tenn. Agr. Exp. Sta. Progress Report, 1939-1942. 1942.

5. NyGard, I. J. Phosphate deficiency in the soils of Montana. Mont. Agr. Exp. Sta. Bul. 240. 1931. 





UNIVERSITY OF ILLINOIS-URBANA

0.630.71L6B BULLETIN. URBANA

$\mathrm{COO2}$

514-528 1945-48 |||||||||||||||||||||||||||||||||||||||||||||||||||| 30112019529343 